\title{
WORKING
}

\section{Dissecting the Impact of Imports from Low-Wage Countries on French Consumer Prices}

\author{
Juan Carluccio ${ }^{1}$, Erwan Gautier ${ }^{2}$, \\ Sophie Guilloux-Nefussi ${ }^{3}$
}

April 2018, WP \#672

\begin{abstract}
We provide a quantitative assessment of the impact of imports from low-wage countries (LWCs) on CPI inflation in France during 1994-2014, using detailed micro data on imports and exports. The share of imports from low-wage countries in consumption increased from about $2 \%$ to $7 \%$, and resulted in a negative impact on CPI inflation of about $0.17 \mathrm{pp}$ per year on average. This effect decomposes in three channels. 1) The substitution channel, capturing the replacement of domestic production by goods from LWCs, accounts for almost -0.05 pp. 2) The rise in the proportion of LWC goods in total imports weighed down on imported inflation. This channel reduced French CPI inflation by 0.06 pp per year. 3) Instrumental variable estimation of the competition channel at the product level shows that the increase in the market share of LWCs in French expenditures led to a negative effect of 0.06 pp on CPI inflation.
\end{abstract}

Keywords: inflation, low-wage countries, imports, globalization, price index, consumers JEL classification: E31; F62

\footnotetext{
${ }^{1}$ Banque de France and University of Surrey. Contact: juan.carluccio@,banque-france.fr

${ }^{2}$ Banque de France and Université de Nantes. Contact: erwan.gautier@banque-france.fr

${ }^{3}$ Banque de France. Contact: sophie.guilloux-nefussi@banque-france.fr

We have benefited from discussions with Huw Dixon, Romain Faquet, Guillaume Gaulier, John Lewis, Romain Restout and participants at the 3rd Conference - Using Micro Price Data Workshop at Cardiff Business School (2017), the 3rd Bank of England/Banque de France International Macroeconomics Workshop (2017), the Theories and Methods in Macroeconomics Conference (2018) and the French Treasury Fourgeaud Seminar (2018).

Working Papers reflect the opinions of the authors and do not necessarily express the views of the Banque de France. This document is available on publications.banque-france.fr/en
} 


\section{NON-TECHNICAL SUMMARY}

A salient feature of the current phase of the globalization process, which begun in the early 1990s, is the rapid and unprecedented integration of emerging economies in world trade. Theory predicts that this evolution should benefit households in developed countries through lowering consumer prices. Figure 1 depicts French CPI inflation and its decomposition into tradable and non-tradable goods inflation. Inflation in tradable goods has been consistently lower since the mid-1990s, corroborating the intuition that international trade openness might have weighed down on inflation over the last two decades.

\section{French Inflation and the Decomposition into Tradables and Non-tradables}

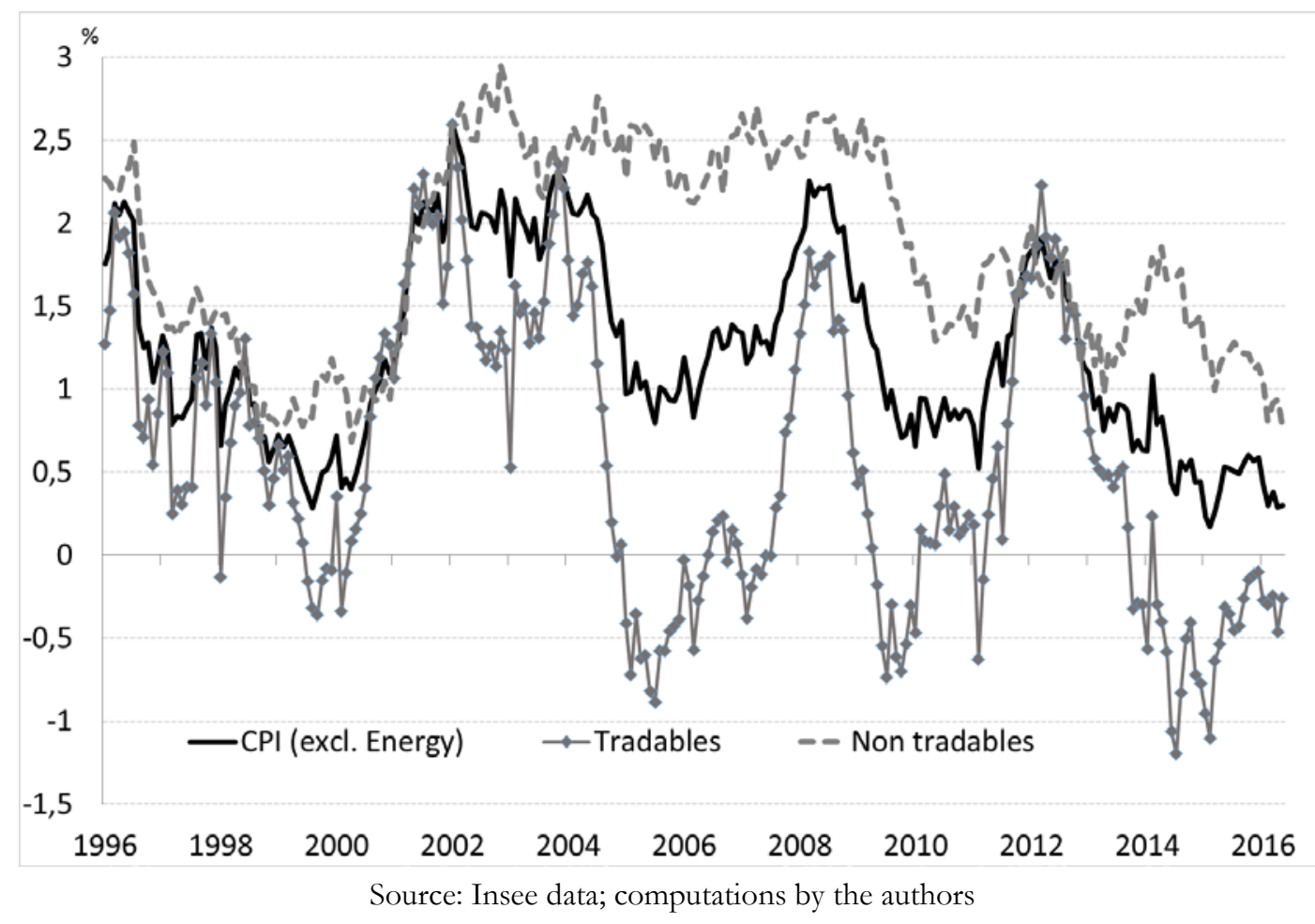

In this paper we provide an assessment of the effect of imports from low-wage countries on inflation in France from 1994 to 2014, quantifying different channels through which the effect operated. We estimate that the share of imports from low-wage countries in French consumption tripled during the period, from $2.4 \%$ in 1994 to $6.9 \%$ in 2014 . The main result of our analysis is that, had this share remained at its 1994 level, French inflation would have been 0.17 pp higher per year on average. For comparison, French CPI inflation (excluding energy) was $1.3 \%$ on average over that period, and inflation in manufactured goods was $0.7 \%$. The single most important country in accounting for these effects is China. The share of Chinese goods in French consumption grew from $0.7 \%$ to $3.5 \%$ over the sample period, a five-fold increase. We find that imports from China alone contributed to reducing French inflation by $0.10 \mathrm{pp}$ on average, accounting for a little more than half of the overall effect.

We use quasi-exhaustive firm-level data from the French Customs with information on quantities and values of imports by product and origin-country, from which we construct detailed import price indices. We create a concordance table to assign each of the imported products to a consumption category in the French CPI. Importantly, these data allow us to 
document the evolution of the share of imports in French consumption by origin country, and to asses by how much those changes have contributed to the dynamics of consumer prices. The use of detailed product-level prices (by country of origin) is key as it allows obtaining measures of differences in price levels, which are essential to our exercise.

We decompose the overall effect into three additive channels. First, imports from low-cost countries replaced goods that were previously produced domestically, with the corresponding shift in the consumption basket resulting in lower overall prices. Our estimations suggest that this Substitution Channel reduced French CPI inflation by 0.05 pp per year on average, accounting for about one third of the overall effect.

A second channel, labeled the Imported Inflation Channel, transits via the evolution of import prices: the rate of growth of imported good prices affects the CPI proportionally to the share of these goods in total consumption. We decompose the evolution of the import price index according to the imports' origins. We find that the increasing share of LWCs in total French imports of consumption goods depressed import price inflation by around 0.4 pp per year. This in turn reduced French CPI inflation by 0.06 pp per year on average.

Finally, raising LWC imports affect the price-setting behavior of domestic firms, thus impacting CPI inflation indirectly, which we label the Competition Channel. Fiercer import competition can negatively impact prices. We find an elasticity of producer prices to LWC import penetration of about -1 . Given the share of imports in total consumption and the increase in imports from LWCs over the period, this third channel accounts for a reduction of CPI inflation by $0.06 \mathrm{pp}$ per year on average

It is worth noting that our estimations do not take into account indirect general equilibrium effects that might take place in the long run (such as price adjustments in tradables resulting from an income effect, or changes in labor and wages). Estimation of general equilibrium effects would require a structural macro model, which is left for future research. This work focuses on quantifying the direct effect on consumer prices.

\section{Impact des importations des pays à bas salaire sur l'inflation française}

\footnotetext{
RÉSUMÉ

Nous évaluons l'impact des importations en provenance des pays à bas salaire sur l'inflation de l'IPC en France entre 1994 et 2014 à partir de données individuelles détaillées sur les importations et les exportations. La part des importations en provenance des pays à bas salaire dans la consommation est passée d'environ $2 \%$ à $7 \%$ et a eu un impact négatif sur l'inflation d'environ 0,17 pp par an en moyenne. Cet effet se décompose en trois canaux. 1) Le canal substitution, qui mesure le remplacement de la production domestique par des biens provenant des pays à bas salaire, représente environ 0,05 pp. 2) L'augmentation de la proportion de biens produits dans des pays à bas salaire dans les importations totales a pesé sur l'inflation importée. Ce canal a réduit l'inflation de l'IPC de 0,06 pp par an. 3) L'estimation par variables instrumentales du canal de la concurrence montre que la hausse de la part de marché des pays à bas salaire a eu un effet négatif d'environ 0,06 pp par an sur l'inflation de l'IPC.

Mots-clés : inflation, pays à bas salaire, importations, mondialisation, prix, consommateurs

Les Documents de travail reflètent les idées personnelles de leurs auteurs et n'expriment pas nécessairement la position de la Banque de France. Ils sont disponibles sur publications.banque-france.fr
} 


\section{Introduction}

A salient feature of the current phase of the globalization process, which begun in the early 1990s, is the rapid and unprecedented integration of emerging economies in world trade. Theory predicts that this evolution should benefit households in developed countries through lowering consumer prices. In policy circles, the idea that raising imports from emerging economies could depress the level and dynamics of consumer prices in rich countries gained renewed attention in light of the low levels of inflation observed in the latter ${ }^{1}$ As an illustration, Figure 1 plots French CPI inflation and its decomposition into inflation of tradables and non-tradables separately. Inflation in tradables is consistently lower since the mid-1990s, corroborating the intuition that international trade openness might have weighed down on inflation over the last two decades.

[Insert Figure 1 here]

In this paper we provide an assessment of the effect of imports from low-wage countries on inflation in France from 1994 to 2014, quantifying different channels through which the effect operated. We aim at providing a detailed understanding of the French case, which also sheds light on the implications of globalization for consumer prices in the Euro Area and other developed countries.

We estimate that the share of imports from low-wage countries in French consumption tripled during the period, from $2.4 \%$ in 1994 to $6.9 \%$ in 2014 . The main result of our analysis is that, had this share remained at its 1994 level, French inflation would have been 0.17 pp higher per year on average. For comparison, French CPI inflation (excluding energy) was $1.3 \%$ on average over that period, and inflation in manufactured goods was $0.7 \%$. The single most important country in accounting for these effects is China. The share of Chinese goods in French consumption grew from $0.7 \%$ to $3.5 \%$ over the

\footnotetext{
${ }^{1}$ ECB President Mario Draghi recently made this concern explicit: "Falling import prices partly explain the subdued performance of core inflation, too. This is because imported consumer products account for around $15 \%$ of industrial goods in the euro area," Introductory speech, ECB Forum on Central Banking, Sintra, 27/7/2017.
} 
sample period, a five-fold increase. We find that imports from China alone contributed to reducing French inflation by 0.10 pp on average, accounting for more than half of the overall effect.

We use quasi-exhaustive firm-level data from the French Customs with information on quantities and values of imports by product and origin-country, from which we construct detailed import price indices. We create a concordance table to assign each of the imported products to a consumption category in the French CPI. Importantly, these data allow us to document the evolution of the share of imports in French consumption by origin country, and to asses by how much those changes have contributed to the dynamics of consumer prices. The use of detailed product-level prices (by country of origin) is key as it allows obtaining measures of differences in price levels, which are essential to our exercise.

We decompose the overall effect into three additive channels. First, imports from low-cost countries replaced goods that were previously produced domestically, with the corresponding shift in the consumption basket resulting in lower overall prices. Our estimations suggest that this Substitution Channel reduced French CPI inflation by 0.05 pp per year on average, accounting for about one third of the overall effect. A second channel, labeled the Imported Inflation Channel, transits via the evolution of import prices: the rate of growth of imported good prices affects the CPI proportionally to the share of these goods in total consumption. We decompose the evolution of the import price index according to the imports' origins. We find that the increasing share of LWCs in total French imports of consumption goods depressed import price inflation by around 0.4 pp per year. This in turn reduced French CPI inflation by 0.06 pp per year on average. Finally, raising LWC imports affect the price-setting behavior of domestic firms, thus impacting CPI inflation indirectly, which we label the Competition Channel. Fiercer import competition can negatively impact prices (e.g. Chen et al. 2009], De Loecker et al. 2016]). We find an elasticity of producer prices to LWC import penetration of about 
-1 . Given the share of imports in total consumption and the increase in imports from LWCs over the period, this third channel accounts for a reduction of CPI inflation by 0.06 pp per year on average $2^{2}$

Our paper contributes to a small but burgeoning literature quantifying the impact of imports from China on consumer prices in advanced economies. Amiti et al. [2017] estimate that imports from China reduced the U.S. manufacturing price index by $7.6 \%$ between 2000 and 2006. 3 Bai and Stumpner 2017], using scanner data for a group of industries, and Jaravel and Sager 2018, using comprehensive data comparable to ours, estimate the impact of Chinese import penetration on U.S. prices. They rely on movements in Chinese exports to locations other than the United States to identify exogenous supply shocks -following the strategy of Autor et al. [2013]. Both papers find negative effects of Chinese imports on U.S. consumer prices, with those in Jaravel and Sager 2018 being close to ours in magnitude. Like the latter works, we use supply shocks to estimate domestic price responses. But our wider approach allows us to evaluate the macroeconomic significance of the effect more precisely by identifying separately each channel through which the overall impact transits. Moreover, we show that, while China is very important, a substantial part of the overall effect is due to other low-wage countries, implying that a proper overall evaluation cannot be restricted to China alone.

Our paper also relates to a previous literature studying the impact of import penetration on other price indices, either import prices or producer prices. A first group of works focuses on the evolution of import prices (Kamin et al. 2006 for the United

\footnotetext{
${ }^{2}$ We consider only imports of goods that are similar to the ones actually produced by domestic firms in order to capture competition in goods' market. Our analysis does not take into account imports of intermediate inputs that might increase domestic firms' productivity with consequences on domestic prices. Hence, the estimate we produce is to be taken as a lower bound to the overall impact of LWC imports on French CPI inflation.

3 Amiti et al. 2017 use China's WTO entry as an exogenous shock, and find that China's lower input tariffs increased its imported goods and boosted firms' productivity, resulting in lower export prices and larger exports values into the United States. Berlingieri et al. 2016 also look at the effect of trade agreements, but those implemented by the European Union between 1993 and 2013. They find that these shocks translated into a reduction in the consumer price index of $0.24 \%$ over the period, with effects being much stronger for high-income countries.
} 
States, Glatzer et al. 2006] for Austria, Mac Coille 2008 and Nickell 2005] for the United Kingdom, Pain et al. 2008 for the Euro Area and the United States). The general conclusion is that the rapid increase in LWC imports depressed import prices in these countries because of the lower prices of imported goods. Interestingly, the magnitude of the effects reported by these works is very close to what we find. A second approach uses reduced-form regressions to assess the indirect impact of LWC imports on producer prices (Auer and Fischer 2010] and Auer et al. [2013] using sector-level data for the US and five European countries, Bugamelli et al. 2015 with individual firm level data for Italy, Gamber and Hung 2001] with product-level data). These papers cover particular aspects that are embedded as different channels in our estimates of the overall impact of LWC imports on CPI inflation.

The rest of the paper is organized as follows. Section 2 provides a simple analytical framework that guides the empirical work. Section 3 presents the data sources and the construction of the main variables. Section 4 presents the results, and Section 5 concludes.

\section{Analytical Framework}

We now present a simple analytical framework that will form the basis of our empirical exercise. The log of the consumer price index at time $t, p_{t}$, can be written as a weighted average of tradables and non-tradables:

$$
p_{t}=\beta_{t} p_{t}^{T}+\left(1-\beta_{t}\right) p_{t}^{N T}
$$

where $p_{t}^{T}$ and $p_{t}^{N T}$ are respectively the log of the price indices of tradables and nontradables at any given year $t$, and $\beta_{t}$ the share of tradables in total consumption.

To quantify the impact of imports originating in low-wage countries it proves useful to further decompose $p_{t}^{T}$ as a weighted average of imported and domestically-produced goods, consumed in shares $\eta_{t}$ and $\left(1-\eta_{t}\right)$ respectively, and with $(\log )$ price indices $p_{t}^{F}$ 
and $p_{t}^{D}$ :

$$
p_{t}^{T}=\eta_{t} p_{t}^{F}+\left(1-\eta_{t}\right) p_{t}^{D}
$$

Here, the price of imported goods is expressed in euros, which means that the effect of exchange rate fluctuations is included in this channel. The reason is that our object of interest is the impact of imports from LWCs for French consumers, whatever the exact source of variations in import prices.

Similarly, the price index of imported goods, $p_{t}^{F}$, can be written as:

$$
p_{t}^{F}=\gamma_{t} p_{t}^{L W C}+\left(1-\gamma_{t}\right) p_{t}^{H W C}
$$

where $p_{t}^{L W C}$ and $p_{t}^{H W C}$ are (log) price indices of imports from low- and high-wage countries respectively, and $\gamma_{t}$ the share of LWC imports in total French imports of consumption goods in year $t$.

Combining expressions (1), (2) and (3), differentiating with respect to time, rearranging terms and denoting inflation rates with $\pi_{t}=\partial p_{t} / \partial t$ we obtain the following expression for the rate of CPI inflation in France (see Appendix A for the full derivation):

$$
\begin{aligned}
\pi_{t}^{C P I} & =\underbrace{\beta_{t} \frac{\partial \eta_{t}}{\partial t} \gamma_{t}\left(p_{t}^{L W C}-p_{t}^{D}\right)}_{\text {Substitution Channel }}+\underbrace{\beta_{t} \eta_{t}\left[\frac{\partial \gamma_{t}}{\partial t}\left(p_{t}^{L W C}-p_{t}^{H W C}\right)+\gamma_{t}\left(\pi_{t}^{L W C}-\pi_{t}^{H W C}\right)\right]}_{\text {Imported Inflation Channel }} \\
& +\underbrace{\beta_{t}\left(1-\eta_{t}\right) \pi_{t}^{D}}_{\text {Competition Channel }}+\Lambda_{t} \\
& \text { with } \Lambda_{t}=\beta_{t}\left[\eta_{t} \pi_{t}^{H W C}+\left(1-\gamma_{t}\right) \frac{\partial \eta_{t}}{\partial t}\left(p_{t}^{H W C}-p_{t}^{D}\right)\right]+\left[\left(1-\beta_{t}\right) \pi_{t}^{N T}+\frac{\partial \beta_{t}}{\partial t}\left(p_{t}^{T}-p_{t}^{N T}\right)\right]
\end{aligned}
$$

Equation (4) makes explicit the role of imports from low-wage countries on CPI inflation, and forms the basis of our empirical analysis. Imports from LWCs affect the evolution of domestic inflation as described by the highlighted terms, labeled "channels":

i. The Substitution Channel measures how changes in the share of consumption of 
imported goods affect the dynamics of CPI prices in France, for a given price-level differential between domestically-produced and imported goods.

ii. The Imported Inflation Channel quantifies the impact of variations in the import price index arising from changes in the share of LWCs in total imports (a "switching effect", first term in the brackets) and in the differential growth of prices between goods produced in LWCs and HWCs (a "differential inflation effect", second term).

iii. The Competition Channel represents the effect of LWC imports on domestic producer prices through increased competitive pressures, which affect inflation in proportion to the share of domestic goods in domestic consumption, $\left(1-\beta_{t} \eta_{t}\right)$.

We quantify the total effect of LWCs on $\pi_{t}^{C P I}$, providing a decomposition into the three above channels from 1994 to 2014. The first two channels are measured with an accounting decomposition method, whereas the third one requires to estimate the reaction of domestic firms to increased LWC import penetration with a reduced-form econometric exercise.

While we will discuss some of the elements in the extra term $\Lambda_{t}$, our aim is not to provide a fully-fledged quantification of it. The first term in $\Lambda_{t}$ measures the impact of imports originating in high-wage countries, through imported inflation and substitution of domestic production 4 The last two terms represent the contribution of non-tradables to overall inflation, through changes in the share of tradables, $\frac{\partial \beta_{t}}{\partial t}\left(p_{t}^{T}-p_{t}^{N T}\right)$, and inflation of non-tradable goods, $\left(1-\beta_{t}\right) \pi_{t}^{N T}$. While imports of consumption goods from LWCs should not affect those terms directly, they can potentially have an impact via general equilibrium effects, stemming from shifts in demand arising from the extra-income generated by the availability of cheaper goods. Quantifying general equilibrium effects requires the estimation of a structural model, which is beyond the scope of this paper

\footnotetext{
${ }^{4}$ Supply shocks in LWCs can affect exports to France and also prices of French imports from HWCs, for example through competition effects, or by affecting worldwide commodity prices. In our analysis we observe equilibrium values for $p^{H W C}$ that incorporate these effects in case they are present.
} 
(and, furthermore, such task would require to comparable price levels of tradables and non-tradables which are highly difficult to compare since it implies to compare prices of goods with prices of services).

\section{Data}

\subsection{Data Sources}

We obtain our sample from different administrative and statistical data sets. Our main source is a quasi-exhaustive administrative file collected by the French Customs Office. It provides the yearly values (in euros) and quantities of imports (by country of origin and product) and exports (by country of destination and product) for all trading firms over the period 1994-2014 $]^{5}$ Trade flows are classified at the CN 8-digit level (EU - Combined Nomenclature). The first six digits are identical to the subheading level (6-digit) of the international Harmonized Nomenclature (HS6), and the last two digits are added by the European Commission. ${ }^{6}$ We restrict our sample to imports and exports of manufactured goods, and we end up with around 14,000 product codes.7

To calculate the share of import in consumption by product we use data on the value of household consumption at a disaggregated level of the COICOP classification, obtained from INSEE 8 To estimate the reaction of domestic prices to import penetration we use Producer Price Indexes (PPI) also from INSEE, corresponding to domestic production

\footnotetext{
${ }^{5}$ Flows with non-EU countries whose value is below 1,000 euros are excluded from the data set. In the case of EU countries, the threshold is larger, varying from 40,000 to 150,000 euros depending on the year. These thresholds leave out a very small proportion of French trade flows.

${ }^{6}$ As an example, CN8 code 18061015 "Cocoa powder, containing added sugar or sweetening matter Containing no sucrose or containing less than $5 \%$ by weight of sucrose (including invert sugar expressed as sucrose) or isoglucose expressed as sucrose" is an extension of HS6 code 18061015 "Cocoa powder, containing added sugar or sweetening matter".

${ }^{7}$ We exclude raw materials (HS01-15, 23, 25-27, 31 and 41) e.g., "Vegetable products", "Mineral products", "Fertilizers" and "Works of art, collector's pieces and antiques", and "Services" (HS97-99). We keep only importers whose main activity falls within NACE Rev-2 codes 10-33. Excluded trade flows are about $5 \%$ of the total value of French imports and exports.

${ }^{8}$ The COICOP is the United Nations' classification of individual consumption expenditures by households according to their purpose. This classification is in particular used to compute CPI inflation.
} 
at the 4-digit level of the French NAF Rev 2 classification (identical to the NACE Rev 2 classification of activities).

\subsection{Country Categories}

We classify source countries into three different categories according to their GDP per capita relative to the French GDP per capita. Following Bernard et al. 2006 and Auer and Fischer [2010], GDPpc ratios are calculated on average over the period 1994-2014, and the composition of groups is held fixed over the sample period. "High-wage countries" are those with GDPpc higher than $75 \%$ of the French GDPpc. "Low-wage countries (LWCs)" are those for which the GDPpc lies between $25 \%$ and $75 \%$ of the French GDPpc. "Very low-wage countries (VLWCs)" includes countries with GDPpc lower than $25 \%$ of France's. We look separately at the cases of China and the New European Union member states (NEUMS), the former grouping countries that joined the EU after 2004 $9^{9}$ Table 1 reports a detailed list of countries by category.

[Insert Table 1 here]

\subsection{Identification of Final Consumption Products}

We define the set of consumption goods as those goods included in the French CPI. Implementing this definition requires mapping CN8 codes to products in the level 3 of the COICOP classification. To our knowledge, a direct concordance table from CN8 to COICOP is not available. We first concord CN8 codes into 6-digit CPA codes (about 3,000 different products), and then we use a concordance table from CPA to COICOP 10 We keep only those products in the Customs data set that match into COICOP categories

\footnotetext{
${ }^{9}$ Bulgaria, Croatia, Cyprus, Czech Republic, Estonia, Hungary, Latvia, Lithuania, Malta, Poland, Romania, Slovakia, Slovenia

${ }^{10}$ The CPA is the statistical classification of products by activity used in the European Union. Concordance tables were obtained from the EU statistical website RAMON: http : //ec.europa.eu/eurostat/ramon/relations/index.cfm?TargetUrl $=L S T_{R} E L$.
} 
(about 4,500 CN8 codes out of a total of 14,000). By definition, products without a match are classified as imports of intermediate goods. As an example, the CN8 code 61112010 , "Babies' garments and clothing accessories, knitted or crocheted: Gloves, mittens and mitts", maps into the COICOP code 03.1.2, "Garments". An example of a CN8 code that has no counterpart in the COICOP classification is 28121011, "Chlorides and chloride oxides".

One important caveat is that some products can be used either for consumption or as inputs, depending on the user (e.g., personal computers). This distinction is impossible to observe in the data, and thus our import penetration measure might be overestimated. For COICOP categories that refer to are services, we assume imports of consumption goods to be zero.

\subsection{Share of Imports in Consumption and Import Price Indices}

Share of imports in consumption: For each 3-digit COICOP code $i$ we define the share of imports in consumption as $\beta_{i t} \eta_{i t}=\frac{M_{i t}}{C_{i t}}$, with $M_{i t}$ being imports of good $i$ and $C_{i t}$ domestic consumption of the same good at time $t$ ( $\beta_{i t}$ is the share of tradables in total consumption and $\eta_{i t}$ the share of tradable goods that are imported, as defined in Section 2). We denote $\beta_{i t} \eta_{i t}^{g}$, with $g \in\{H W C s, L W C s, V L W C s, N E U M S, C h i n a\}$, the share of imports from each of the five country groups in domestic consumption of good i. By construction: $\eta_{i t}=\sum_{\forall g} \eta_{i t}^{g}$.

Unlike imports, the value of consumption reported by INSEE includes VAT and distribution margins, as it aims at reflecting prices actually paid by consumers. To obtain comparable figures we first scale import values with a uniform $20 \%$ distribution margin, corresponding to the average margin of the retail sector as estimated by Andrieux and d'Isanto 2015, which includes both transportation and distribution costs. The sample of products covered by Andrieux and d'Isanto 2015 for this calculation is close to the 
set of tradable goods purchased for consumption purposes we consider 11 Then, we apply VAT rates to the import values inclusive of margins, the normal rate (20\% since January 2014) applies to most of our imported products whereas a reduced rate of $5.5 \%$ applies to food products.

Import Price Indices: We proxy product-level prices with unit values, defined as the ratio of value to quantity. We calculate unit values at the product(CN8)-country level, the most disaggregated level available, in order to minimize measurement errors. For each country category $g$ and product $i$, we first calculate a price index $P_{g i, 0}^{F}$ as a weighted geometric average of unit values, where $t=0$ is the first year this product is in our sample. Weights $\gamma_{i c}$ are the share of imports of each product $i$ and country $c$ in total French imports of product $i$ from country-group $g$ :

$$
P_{g i, 0}^{F}=\prod_{c \in g} P_{i c, 0}^{\gamma_{i c, 0}}
$$

For the remaining years we compute the import price level for product $i$ imported from country group $g$ at time $t$ as:

$$
P_{g i, t}^{F}=P_{g i, t-1}^{F} \pi_{g i, t}^{F}
$$

where

$$
\pi_{g i, t}^{F}=\frac{\prod_{c \in g_{t-1}}\left(P_{i c, t}^{F}\right)^{\gamma_{i c, t-1}}}{\prod_{c \in g_{t-1}}\left(P_{i c, t-1}^{F}\right)^{\gamma_{i c, t-1}}}
$$

Naturally, some product-country pairs drop out of the sample over time. In such cases, we impute to those goods a price change equal to the average change of the remaining of the index. This methodology is in line with the standard procedure proscribed by the IMFs Export and Import Price Index Manual (International Monetary Fund [2009]) and,

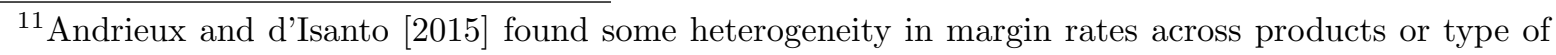
outlets but we cannot apply different margin rates to different types of outlets or different goods. Overall, these differences are going from $10 \%$ in communication products sold in supermarkets to $40 \%$ for frozen products sold in specialized outlets.
} 
as highlighted by Atkeson and Burstein [2008], is equivalent to excluding these goods at the time they drop from the index and re-normalizing the weights for the remaining goods to sum up to one.

For each product $i$, the import price level is then obtained from:

$$
P_{i, t}^{F}=\prod_{\forall g}\left(P_{g i, t}^{F}\right)^{\gamma_{g i, t}}
$$

and import price inflation of product $i$ is calculated as:

$$
\pi_{i, t}^{F}=\ln \left(P_{i, t}^{F}\right)-\ln \left(P_{i, t-1}^{F}\right)
$$

The aggregate import price inflation is calculated as the weighted average of all products' inflation:

$$
\pi_{t}^{F}=\sum_{\forall i} \gamma_{i, t} \pi_{i, t}^{F}
$$

where $\gamma$ always stands for the share in total imports: $\gamma_{i, t}$ is the share of imports of product $i$ in total imports, $\gamma_{g i, t}$ is the share of imports of product $i$ from country group $g$ in total imports.

$$
\text { [Insert Figure } 2 \text { here] }
$$

Figure 2 shows the evolution of the import price index over the period 1995-2014 (we use 1994 as the base year, thus the inflation measures start in 1995). To check the validity of our index, we also plot two aggregate measures of import inflation published by INSEE. The closest official series is the monthly import price index for the manufacturing industry, constructed with surveys to individual firms starting in 2005. As can be seen, the inflation rate calculated using this price index correlates very strongly with our import price inflation (correlation coefficient of 0.73 ). To have an idea of how well our index represents import data previous to 2005, we include the year-on-year percentage change in the import deflator from the National Accounts. This index covers a wider range 
than ours since it includes not only manufactured goods but also services and extractive industries such as mining and quarrying, with the latter making inflation more volatile. Still, the correlation with the import price index is high (correlation coefficient of 0.55). Thus, we can be safe in that our measure of import prices, calculated with unit values from the Customs data set, reflects the aggregate evolution of French import prices well.

\section{Results}

We now provide a quantification of the impact of imports from low-wage countries on French CPI inflation. We follow the decomposition described in Section 2 and present the results for each channel successively.

\subsection{Substitution Channel}

As discussed in Section 2, imports can lower domestic inflation because consumers can substitute domestically-produced goods with cheaper imported goods. On average over our sample period, the share of tradable goods in total consumption $\left(\beta_{t}\right)$ is $46 \%$ and the average share of imports in tradable consumption $\left(\eta_{t}\right)$ is $32 \%$. Thus, the average share of imports in total consumption $\left(\beta_{t} \eta_{t}\right)$ is a little higher than $14 \%$. Figure 3 provides the evolution of the share of imports in total consumption for 1994-2014. Import penetration shows a clear upward trend, going from $10 \%$ in 1994 to $17 \%$ in 2014 . On average, the import share in consumption increased by 0.3 pp per year over the period.

[Insert Figure 3 here]

Import penetration can increase for two reasons: a rise in the weight of tradable goods in the CPI inflation or/and an increase of the share of imports in tradable good consumption. Figure 3 decomposes changes in import penetration according to these two factors. Bars in light grey represent the contribution of change in the share of tradables in 
the CPI $\left(\eta_{t} \times \frac{\partial \beta_{t}}{\partial t}\right)$ and the bars in dark grey, give the contribution of changes in the share of imports in tradable consumption $\left(\beta_{t} \times \frac{\partial \eta_{t}}{\partial t}\right) \cdot 12$ The average year-on-year change in the share of imports in tradables is $+0.8 \mathrm{pp}$, contributing to the increase import penetration by $0.37 \mathrm{pp}$ on average per year $(=0.46 \times 0.8)$. This increase happened in spite of the reduction in the share of tradables in total consumption, and the rising share of services: $\beta_{t}$ passed from $49 \%$ in 1995 to $43 \%$ in 2014 , contributing negatively to the evolution of import penetration by approximately $-0.07 \mathrm{pp}$.

A rise in import penetration lowers inflation only if imported goods are cheaper than the goods they replace. Therefore, estimating the effect of increasing imports on CPI French inflation requires a measure of the price differential between imported and domestically-produced goods $\left(p_{t}^{F}-p_{t}^{D}\right)$. Given the lack of available data on the price levels of domestically-produced goods, we proxy domestic prices with French export unit values, as in Emlinger and Fontagné [2013]. We compute export unit values using the same methodology we described in Section 3.4 for the case of imports. We then select those CN8 products that are both imported $(M)$ and exported $(X)$ by French firms, compute the ratio $\ln \left(P_{t}^{M}\right)-\ln \left(P_{t}^{X}\right)$ by product (as a proxy for $p_{t}^{F}-p_{t}^{D}$ ) and compare their levels and evolution over time. Export prices are collected at their F.O.B. values (Free on Board), that is at the value of the good at the origin country's border, and thereby excluding transportation and freight costs. Import prices are on the other hand collected at their C.I.F. values at the importing country's border, and are inclusive of Cost, Insurance and Freight costs. To account for this wedge we add 5\% to all export unit values, based on the mean estimate of the CIF-FOB margin for France during the same period of this study, given by Miao and Fortanier [2017].

Figure 4 plots the yearly average (across products) ratio of import prices to export prices $\ln \left(P_{t}^{M}\right)-\ln \left(P_{t}^{X}\right)$. The grey line is constructed using all import origins. On average over the period, import prices were around 15\% lower than export prices and

\footnotetext{
${ }^{12}$ The total change is $\frac{\partial\left(\beta_{t} \eta_{t}\right)}{\partial t}=\frac{\partial \beta_{t}}{\partial t} \eta_{t}+\beta_{t} \frac{\partial \eta_{t}}{\partial t}$.
} 
their ratio remained rather stable over time, with a slightly decreasing trend. Given that the share of imports in French consumption increased by 0.37 pp per year, and that imports were $15 \%$ cheaper, the overall effect of raising imports (irrespective of their origin) on French CPI inflation was of -0.05 pp per year on average.

[Insert Figure 4 here]

In order to quantify the contribution of LWC to this overall effect, we decompose price differentials by origin. We find that import prices from HWCs are on average $3 \%$ cheaper than French export prices, this ratio being fairly constant over time (Figure 4 . black line). This indicates very small differences between prices of goods produced in France and those produced in other high-wage countries (we obtain similar results when restricting to export prices destined to HWCs only). The price differential with imports from LWCs as a whole (i.e. China, NEUMS and other LWCs) is much larger than the one obtained for HWC imports. The average log price differential over 1994-2014 is of 41\%.13 This difference slightly declined over time. Price ratios calculated for Chinese and NEUMS imports do not show strong differences. ${ }^{14}$

We calculate the contribution of LWC imports to the Substitution Channel using the formula in equation (4). We find a negative effect of a little less than $-0.05 \mathrm{pp}$ on average per year: $\beta_{t} \frac{\partial \eta_{t}}{\partial t} \gamma_{t}\left(p_{t}^{L W C}-p_{t}^{D}\right)=0.46 \times 0.8 \times 0.31 \times(-0.41)=-0.05$. The impact of HWC imports is very small (less than $-0.01 \mathrm{pp}$ ). Thus, almost the entire effect of the substitution channel is due to cheaper imports from low-wage countries.

Import penetration is strongly concentrated in some specific products (i.e. Clothing, Furnishings and Recreation and Culture goods), and the overall effect reported above

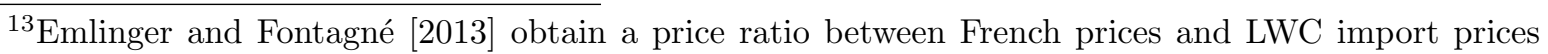
higher than 2 over the period 2000-2010. However, one difference with Emlinger and Fontagné [2013] is that we calculate price ratios at level 8 of $\mathrm{CN}$ classification whereas they compare prices at level 6 of the $\mathrm{CN}$ classification.

${ }^{14}$ Note that the price-differentials we document should be taken as upper bounds, due to likely biases arising from quality differences, if the average quality of French exports is higher than that of French imports from LWCs. Estimating quality differences requires the use of a structural model, which is out of the scope of our paper.
} 
masks strong heterogeneity across product categories. Figure 5 plots the share of imports in consumption by product category (level 1 of COICOP classification). In 1994, LWC imports were concentrated in Clothing, Furnishings and Recreation and Culture, with imports representing between $20 \%$ and $34 \%$ of consumption. These three sectors represented altogether $20 \%$ of the CPI but about half of total imports of consumption goods. The largest increases in import penetration are observed for Clothing and Furnishings. In 2014, imports account for about $75 \%$ of French consumption of Clothing, $55 \%$ of Furnishings. In Communication, which includes cell phones and related devices, import penetration has increased greatly, from $0 \%$ to about $12 \%$.

\section{[Insert Figure 5 here]}

Table 2 provides an estimation of Channel 1 by product category. For each product, we calculate the share of tradables, the average change in import penetration, the LWC share in all imports and the price differential. The fourth column gives our estimation of the individual product substitution effect. The largest effects are obtained for Clothing and Furnishings, being of -0.8 and -0.2 pp respectively. On the contrary, much smaller effects are obtained for Recreation and Culture, Communication and other goods and services. The last column reports the contribution of each product category to the aggregate substitution effect (i.e. taking into account the share of each product category in the CPI): $80 \%$ of the overall effect is due to Clothing and Furnishings (-0.04 pp out of $-0.05 \mathrm{pp}$ for the overall effect).

[Insert Table 2 here]

\subsection{Imported Inflation Channel}

Imports from low-wage countries can affect French imported inflation if households replace consumption of goods from HWCs by consumption of goods from LWCs and their price levels are different, or if, for a given import structure, prices of goods from LWCs grow 
more slowly than other imports (or a combination of both). Figure 6 plots the share of each origin in total imports. During the period under analysis, imports of consumption goods continuously switched towards goods from LWCs and away from those from HWCs. In 1994, high-wage countries accounted for around $76 \%$ of total French imports, declining steadily to reach $57 \%$ in 2014 . The main drivers of this increase in the share of LWCs are China and the NEUMS.

$$
\text { [Insert Figure 6 here] }
$$

The inflation differential between HWC and LWC imports over the same period (see Figure 7), was rather small, with the inflation rate of French imports from LWCs being slightly higher than that of imports from HWCs.

\section{[Insert Figure 7 here]}

We decompose import price inflation into a "switching effect" and a "differential inflation effect" using the formula of the Imported inflation channel in equation (4). Import inflation increased by about $0.6 \%$ per year over the sample period, as shown in Figure 7 (same annual growth rate of the import deflator from the National Accounts). LWC imports had a strong negative contribution, close to $-0.4 \mathrm{pp}$ on average per year. Figure 8 plots the two components of the imported inflation channel, the switching effect in dark grey bars and the inflation differential effect in light grey bars. The overall effect of LWC imports on French import inflation is the combination of a strong negative switching effect of $-0.47 \mathrm{pp}$ on average, and a rather small positive impact of the inflation differential of $+0.06 \mathrm{pp}$. In other words, LWC imports gained market shares, depressing import prices, in spite of the fact that prices of imports from LWCs increased a little faster than those of goods imported from HWCs.

[Insert Figure 8 here] 
The negative contribution of the switching effect was strongest during 2000-2012 $(-0.59 \mathrm{pp})$. It is also quite heterogeneous across groups of LWCs. Figure 9 plots the contribution of each country category to the switching effect and shows that almost all of variation is due to imports from China: $-0.37 \mathrm{pp}$ out of $-0.47 \mathrm{pp}$ per year on average ${ }^{15}$ The contribution of NEUMS is about $-0.08 \mathrm{pp}$ and that of very low-wage countries and intermediate low-wage countries around $-0.01 \mathrm{pp}$.

\section{[Insert Figure 9 here]}

The contribution of the inflation differential is positive on average, but varies over time. It was negative in the years at the beginning of the 2000's $(-0.24 \mathrm{pp}$ on average from 2001 to 2004), meaning that import prices from LWCs grew faster that those from HWCs over that period. After the crisis, the inflation differential has been positive and large from 2009 to 2012 (with a contribution of +0.30 pp per year on import price inflation on average). The post-crisis positive effect is almost fully driven by Chinese imports. Table 3 provides an international comparison of LWC contribution to import inflation in several countries. All studies point to a negative effect of LWC imports on import inflation, and of a magnitude which is very close to the one we obtain.

Eventually, the overall imported inflation channel is the sum of the switching effect $\left(\frac{\partial \gamma_{t}}{\partial t}\left(p_{t}^{L W C}-p_{t}^{H W C}\right),-0.47 \mathrm{pp}\right.$ on average $)$ and the inflation differential effect $\left(\gamma_{t}\left(\pi_{t}^{L W C}-\pi_{t}^{H W C}\right)\right.$, $+0.06 \mathrm{pp}$ on average), weighted by the share of imports in domestic consumption $\left(\beta_{t} \eta_{t}\right.$, 0.14 on average). We obtain that the contribution of the imported inflation channel to CPI inflation is $-0.06 \mathrm{pp}(=0.14 \times[-0.47+0.06]=-0.06$, see also Table 7 $)$.

Looking by products (Table 4), the imported inflation channel is at play in almost all COICOP category except Food, Alcohol \& Tobacco and Restaurants \& Hotels. This channel weighed down on consumer inflation everywhere but in Communication.

[Insert Table 4 here]

\footnotetext{
${ }^{15}$ The highest values for the switching effects coincide with China's entry in the WTO.
} 


\subsection{Competition Channel}

Channel 3 transits through the pro-competitive effect of imports from LWCs. Trade integration with low-wage countries implies an increase in competitive pressures that might push domestic producers to lower their prices. In our framework, the impact of changes in the rate of inflation of domestically-produced goods $\pi^{D}$ affects CPI inflation through the term $\beta_{t}\left(1-\eta_{t}\right) \pi_{t}^{D}$ in equation (4).

In this section we estimate the impact of LWC import penetration on sector-level domestic producer price inflation. Our estimating equation is the following:

$$
\pi_{i, t}^{D}=\Psi \Delta S_{i, t}^{L W C}+\kappa \Delta \text { labcost }_{i, t}+\eta \Delta \text { inputcost }_{i, t}+\lambda_{t}+\nu_{i}+\epsilon_{i, t}
$$

where $\pi_{i, t}^{d}$ is the log-difference of producer prices (domestic market) between year $t-1$ and $t$ for product $i, \Delta S_{i, t}^{L W C}$ is the variation of the share of imports from LWC in domestic consumption of good $i, \Delta l a b c o s t$ is the annual growth rate of labour cost in sector $i$ and $\Delta$ inputcost the annual change in the intermediate input cost for sector $i, \lambda_{t}$ is a time fixed-effect and $\nu_{i}$ is a product fixed effect.

$\Psi$ is our coefficient of interest. We expect $\Psi<0$, implying that increases in the market share of low-wage imports in sector $i$ reduce domestic inflation. Notice that the reduced-form equation (6) and the hypothesis $\Psi<0$ are very general and arise in a broad group of theoretical models of variable markups. In Appendix B, we describe in more details a simple model that delivers this equilibrium relationship in the case of oligopolistic competition between domestic and foreign producers.

We estimate equation (6) using data on producer price inflation at the 4-digit level of the CPA classification from INSEE. LWC import penetration is defined as total imports of country category divided by total imports plus French domestic production (excluding

production for exports): $S_{t}(L W C)=\frac{M_{i, t}^{L W C}}{Y_{i, t}+M_{i, t}-X_{i, t}}$, with $Y_{i, t}, M_{i, t}$ and $X_{i, t}$ representing sector $i$ 's total domestic production, imports and exports. We measure imports with 
the trade data described in Section 3 and we obtain domestic production from Eurostat's PRODCOM survey. We concorde trade data at the HS 6-digit level to production data at the CPA Rev2 level using a concordance table from the European Commission's RAMON website. We define $S_{t}$ using imports from all LWCs and alternatively using imports from China only. Following Auer and Fischer 2010] and Auer et al. 2013], the denominator is averaged over the full sample to reduce concerns that results might be driven by the responses of the French production to French prices ${ }^{16}$ Annual change in total labor costs and in intermediate input costs are calculated using sector-level data from STAN-OECD Database (at level 2 of the NACE classification). These variables capture changes in marginal costs.

OLS estimation of $\Psi$ might suffer from endogeneity bias. Both domestic prices and imports depend positively on (unobserved) demand shocks in France, which if present would generate a positive correlation between both variables. Similarly, unobserved productivity shocks affecting French producers might lower prices and change demand towards domestic goods and away from imports. Given these considerations, OLS estimations are likely to provide upward-biased coefficients of the true effect of low-wage import penetration on domestic prices. To account for this potential bias we use instrumental variables that generate variations in low-wage countries' market shares while being exogenous to movements in France's demand and supply. We identify supply shocks in LWCs with the year-on-year growth rate of manufacturing exports from each LWC to the world, excluding France, in the spirit of Autor et al. [2013]. As argued by Auer and Fischer [2010], these supply shocks should have a relatively higher impact in sectors for which LWCs have a comparative advantage with respect to France. This is captured with a measure of each sector's labor intensity. Thus, the instrument combines a variable that varies over time with a time-invariant sector characteristic. Hence our instrumental variable varies both over time and across products.

\footnotetext{
${ }^{16}$ Results are similar if we relax this assumption.
} 
We estimate equation (6) with Panel IV 2SLS regressions. In all specifications, we compute heteroskedasticity robust standard errors. Appendix C provides details on the variables construction and reports the results of the first-stage regressions. In the firststage equation, our instrumental variable is significant at 1\%-level for specifications using all products whereas when restricting the sample to consumption goods or high-import penetration sector estimated parameters are statistically significant at $5 \%$ or $10 \%$ level. Our instrument also passes several tests of weak instrument when considering all products whereas when we restrict our sample to some product categeories we loose some identification power.

\section{[Insert Table 5 here] \\ [Insert Table 6 here]}

Tables 5 and 6 report the results of both the OLS and IV regressions respectively for all LWCs, and restricting the import penetration variable to China only (i.e. $\Delta S_{i, t}^{C H}$ ). Columns (1) and (2) use the full sample of $154 \mathrm{CPA}$ products. An increase in the market share of imports coming from LWCs has a small positive effect on domestic producer-price inflation. Controlling for endogeneity, we find a strong negative effect of LWC import penetration on producer price inflation. A $1 \%$ increase in the share of LWCs in any given sector's demand decreases domestic producer prices by $1.2 \%$, an effect statistically significant at 5\%. Auer et al. 2013 report very similar magnitudes for France (between -1 and $-2.7 \%$ ). The regression using only China provides a negative but non-significant OLS estimates. Like for LWC, the negative effect is highly amplified in the IV regressions: a 1\%-increase in Chinese import penetration leads to lower domestic inflation by $1.9 \mathrm{pp}$. Notice that IV estimates are also much less precise.

In columns (3) and (4) we restrict the sample to consumption goods (that is, those that can be matched with COICOP, in a similar vein as described in Section 3). The elasticity of French PPI to import penetration is estimated at -0.8 for all LWCs and 
-1.1 in the case of China only. The estimates are much noisier in the light of the smaller sample size and become not significant. The last two columns of Tables 5 and 6 report results where we restrict the sample to sectors with a high import penetration (larger than $33 \%$ ), obtaining qualitatively similar effects as with the full sample.

With the elasticities of import penetration to producer prices in hand, we are able to quantify the total effect of the pro-competitive channel on French CPI inflation using $\beta_{t}\left(1-\eta_{t}\right) \pi_{t}^{D}$. On average, $46 \%$ of CPI expenditures are in tradable goods, decomposing into $32 \%$ of imported goods and $68 \%$ of domestically-produced goods. Thus, $32 \%(=0.46$ $\times 0.68)$ of CPI consumption is produced by domestic firms whose price-setting behavior is potentially affected by import competition. The average increase in LWC market share over the sample period is $0.17 \mathrm{pp}$. Using the elasticity estimates obtained from the IV regressions (on all goods, column 2) ${ }^{17}$ it gives a total effect of the Competition channel of $0.06 \mathrm{pp}(=-1.2 \times 0.17 \times 0.32)$. Using the elasticity obtained from the IV regressions with only consumption goods, the total contribution of Channel 3 is around -0.04 . However, we should point out that our elasticities are estimated with some degree of imprecision. If we take the boundaries of the $90 \%$ confidence interval of our parameter estimates for all goods, the total contribution of Channel 3 would be between -0.01 and $-0.12 \mathrm{pp}$. When looking at the effect of China alone, the average change in import penetration is a bit smaller (less than 0.1 pp per year) but the impact on producer price inflation is a little higher (1.9), leading to an overall effect of a little more than $0.02 \mathrm{pp}$ on CPI inflation $(=-1.9 \times 0.1 \times 0.32)$.

\section{Conclusion}

We can now provide our estimate of the total effect of LWC imports on CPI inflation in France during 1994-2014. It is the sum of the three channels as shown in equation (4).

\footnotetext{
${ }^{17}$ We prefer this estimates to the one including only consumption goods because using the sample of all goods allows us to have a better identification power. Moreover, estimates for all goods or restricting to consumption goods are not statistically different.
} 
The Substitution Channel, which transits through the changes in consumption favoring foreign goods, had a negative effect on French CPI inflation that we estimate to be of $0.05 \mathrm{pp}$ on average. The Imported Inflation Channel, which quantifies the impact of variations in the import price index arising from changes in the share of LWCs in total imports, is estimated to have reduced French import inflation by $-0.4 \mathrm{pp}$, resulting in a negative impact of $-0.06 \mathrm{pp}$ on average on CPI inflation. Finally, the Competition Channel, which measures the impact on the CPI that is due to the local producers' price responses to increased competitive pressures from LWCs, is estimated to have had a negative impact on CPI inflation of about $-0.06 \mathrm{pp}$. Therefore, the main result provided by our analysis is that, during 1994-2014, LWC imports have contributed negatively to the evolution of French CPI inflation, by about -0.17 pp per year on average. Put differently, our estimations imply that had the imports from LWCs remained at their 1994 level, French inflation would have been 0.17 pp higher per year on average during the 20 years that followed.

Among LWCs, China clearly stands out. Imports from China increased from $7 \%$ to almost $21 \%$ of total French imports of consumption goods. In terms of share in total French consumption, they passed from $0.7 \%$ to $3.5 \%$ over the same period. Table 7 shows the calculations of the different channels for China alone. The total effect is estimated to be $-0.10 \mathrm{pp}$, therefore explaining more than half of the overall effect of LWCs. The raise of China as a mega-trader has been widely documented, and France is no exception to the Chinese dominance of international trade during the past decades.

Over the period 1994-2014, the total effect of LWC imports on CPI inflation has been somewhat higher since the beginning of 2000s. On average, the overall effect is a little smaller than -0.10 pp before 2002 whereas it is closer to -0.20 pp after. This comes in particular from a higher effect transiting through the modification of structure by country origin of our imports (channel 2).

It is worth noting that, by focusing on year-to-year changes, the estimates we provide 
are to be interpreted as an average of successive short-run effects. Our estimations do not take into account possible effects on the prices of non-tradables resulting from income effects due to cheaper tradable goods. Neither do we measure changes in labor and wages that might result from openness to international trade in the long run, nor reaction of monetary policy. Estimation of such general equilibrium effects would require a structural macro model, which is left for future research. This work focuses solely on quantifying the short-run direct impact on consumer prices, which we believe can be useful for guiding monetary policy decisions. In the long run, appropriate adjustments in monetary policy should ensure that inflation goes back to the target. 


\section{References}

Amiti, Mary, Mi Dai, Robert C. Feenstra, and John Romalis, "How Did Chinas WTO Entry Benefit U.S. Consumers?," NBER Working Papers 23487, National Bureau of Economic Research, Inc June 2017.

Andrieux, Virginie and Aurelien d'Isanto, "Des marges commerciales variees selon les produits, mais proches entre grandes surfaces," Insee Focus, n45, Insee 2015.

Atkeson, Andrew and Ariel Burstein, "Pricing-to-Market, Trade Costs, and International Relative Prices," American Economic Review, December 2008, 98 (5), 19982031.

Auer, Raphael A. and Andreas M. Fischer, "The effect of low-wage import competition on U.S. inflationary pressure," Journal of Monetary Economics, 2010, 57 (4), $491-503$.

_, Katrin Degen, and Andreas M. Fischer, "Low-Wage Import Competition, Inflationary Pressure, and Industry Dynamics in Europe," European Economic Review, 2013, 59, 141-166.

Autor, David H., David Dorn, and Gordon H. Hanson, "The China Syndrome: Local Labor Market Effects of Import Competition in the United States," American Economic Review, October 2013, 103 (6), 2121-68.

Bai, Liang and Sebastian Stumpner, “,” Mimeo, University of Edinburgh. 2017.

Bank of Finland, "Finnish Import Prices and Globalization," Monthly Bulletin 3, Bank of Finland 2006.

Berlingieri, Giuseppe, Holger Breinlich, and Swati Dhingra, "The Impact of Trade Agreements on Consumer Welfare," CEPR Discussion Papers 11148, C.E.P.R. Discussion Papers March 2016. 
Bernard, Andrew B., Bardford Jensen, and Peter K. Schott, "Survival of the best fit: Exposure to low-wage countries and the (uneven) growth of U.S. manufacturing plants," Journal of International Economics, 2006, 68 (1), 219-237.

Bugamelli, Matteo, Silvia Fabiani, and Enrico Sette, "The Age of the Dragon: The Effect of Imports from China on Firm-Level Prices," Journal of Money, Credit and Banking, 09 2015, 47 (6), 1091-1118.

Cardoso, Fatima and Paulo Soares Esteves, "The effects of Low-Cost Countries on Portuguese Manufacturing Import Prices," Working Paper 4, Banco de Portugal 2008.

Chen, Natalie, Jean Imbs, and Andrew Scott, "The dynamics of trade and competition," Journal of International Economics, February 2009, 77 (1), 50-62.

Coille, Conall Mac, "The impact of low-cost economies on UK import prices," Quarterly Bulletin, Bank of England 2008.

De Loecker, Jan, Pinelopi K. Goldberg, Amit K. Khandelwal, and Nina Pavcnik, "Prices, Markups, and Trade Reform," Econometrica, 2016, 84 (2), 445-510.

Emlinger, Charlotte and Lionel Fontagné, "(Not) Made in France ," La lettre du CEPII, 2013, 333,--.

Gamber, Edward N and Juann H Hung, "Has the Rise in Globalization Reduced U.S. Inflation in the 1990s?," Economic Inquiry, January 2001, 39 (1), 58-73.

Glatzer, Ernst, Ernest Gnan, and Maria Teresa Valderrama, "Globalization, Import Prices and Producer Prices in Austria," Monetary Policy \& the Economy, 2006, (3), 2443.

International Monetary Fund, "Export and Import Price Index Manual: Theory and Practice," [Washington, D.C.]: International Monetary Fund, 2009, 2009. 
Jaravel, Xavier and Erick Sager, "What Are the Price Effects of Trade? Evidence From the U.S. and Implications for Quantitative Trade Models," Technical Report, mimeo February 2018.

Kamin, Steven B., Mario Marazzi, and John W. Schindler, "The Impact of Chinese Exports on Global Import Prices," Review of International Economics, 05 2006, $14(2), 179-201$.

Miao, G. and F. Fortanier, "Estimating Transport and Insurance Costs of International Trade," OECD Statistics Working Papers, OECD April 2017.

Nickell, Stephen, "Why has Inflation Been So Low Since 1999?," Speech at the Bank of England Monetary Policy Committee and London School of Economics, Bank of England 2005.

Pain, Nigel, Isabell Koske, and Marte Sollie, "Globalisation and OECD consumer price inflation," OECD Journal: Economic Studies, 2008, 2008 (1), 1-32.

Sveriges Riksbank, "Why are Swedish import prices so low?," Inflation Report 2005/2, Sveriges Riksbank 2005. 
Table 1: List of Countries by Country Categories

Group of countries

High-wage countries

GDP per capita above $75 \%$ of France's:

EU countries, US, Canada, UK, Japan,South Korea,

Australia, New Zealand, Israel...

Low-wage countries

GDP per capita between $25 \%$ and $75 \%$ of France's

- New EU member states

Bulgaria, Croatia, Cyprus, Czech, Estonia, Hungary, Latvia, Lithuania, Malta, Poland, Romania, Slovakia, Slovenia

- Other low-wage countries

Turkey, Brazil, Mexico, Malaysia, Russia, Argentina,...

Very low-wage countries

GDP per capita below 25\% of France's

- China (including Hong-Kong)

- Other Very low wage countries

India, Thailand, Tunisia, Morocco, Indonesia, Philippines,

Vietnam, Egypt, Pakistan, Ukraine, Ivory Coast,... 
Table 2: Substitution Channel - Decomposition by COICOP Product Categories (average, 1994-2014)

\begin{tabular}{|c|c|c|c|c|c|c|}
\hline $\begin{array}{l}\text { COICOP } \\
(\% \text { of } \mathrm{CPI})\end{array}$ & $\begin{array}{c}\text { Share of } \\
\text { tradables } \\
\beta\end{array}$ & $\begin{array}{c}\Delta \text { imp. } \\
\text { pen. } \\
\frac{\partial \eta_{t}}{\partial t}\end{array}$ & $\begin{array}{c}\text { Share of } \\
\text { LWC imp. } \\
\gamma\end{array}$ & $\begin{array}{l}\text { Price diff. } \\
p^{L W C}-p^{D}\end{array}$ & $\begin{array}{c}\text { Channel } \\
1\end{array}$ & $\begin{array}{l}\text { Contrib. } \\
\text { CPI infl. } \\
\text { in pp }\left(\times 10^{2}\right)\end{array}$ \\
\hline $\begin{array}{l}\text { 1- Food and non-alcohol. } \\
\text { beverages }(15 \%)\end{array}$ & 0.73 & 0.35 & 0.12 & -0.17 & -0.01 & -0.1 \\
\hline $\begin{array}{l}\text { 2- Alcoholic beverages } \\
\text { and tobacco }(4 \%)\end{array}$ & 1.00 & 0.10 & 0.06 & -0.19 & 0.00 & 0.0 \\
\hline $\begin{array}{l}\text { 3- Clothing and } \\
\text { footwear }(4 \%)\end{array}$ & 0.97 & 2.15 & 0.62 & -0.59 & -0.76 & -3.0 \\
\hline $\begin{array}{l}\text { 4- Housing, water, elect., } \\
\text { gas... }(14 \%)\end{array}$ & 0.18 & 0.09 & 0.15 & -0.33 & 0.00 & 0.0 \\
\hline $\begin{array}{l}5 \text { - Furnishings, house } \\
\text { services }(6 \%)\end{array}$ & 0.85 & 1.26 & 0.25 & -0.62 & -0.16 & -1.0 \\
\hline 6- Health $(10 \%)$ & 0.27 & 0.14 & 0.07 & -0.42 & 0.00 & 0.0 \\
\hline 7- Transport $(16 \%)$ & 0.43 & 0.21 & 0.09 & -0.34 & 0.00 & 0.0 \\
\hline 8- Communication (3\%) & 0.10 & 0.59 & 0.45 & -0.89 & -0.02 & -0.1 \\
\hline $\begin{array}{l}9 \text { - Recreation and } \\
\text { culture }(8 \%)\end{array}$ & 0.53 & 0.27 & 0.34 & -0.41 & -0.02 & -0.2 \\
\hline $\begin{array}{l}\text { 11- Restaurants } \\
\text { and hotels }(8 \%)\end{array}$ & 0.00 & - & - & - & - & 0.0 \\
\hline $\begin{array}{l}\text { 12- Miscellaneous } \\
\text { goods and services }(13 \%)\end{array}$ & 0.29 & 0.25 & 0.28 & -0.71 & -0.01 & -0.2 \\
\hline
\end{tabular}

Note: The first column "share of tradables" reports for each COICOP aggregate category the ratio between total imports of a given product (source: Customs) and the total French consumption of tradable goods (source: Insee, national accounts), including VAT and distribution margins. " $\Delta$ in import pen." is the average year-on-year change in the share of imports in French tradables. "Share of LWC imports" reports the share of imports from low-wage countries in overall French imports. "Average price diff." is the average difference in the (log) level of prices of goods imported from LWCs and the ones produced in France (this latter price is proxied by French export prices) (we also take into account a wedge of $5 \%$ bewteen CIF imports an FOB exports). "Channel 1" is calculated by COICOP 1 as the product of column (1), (2), (3) and (4) and is the impact on the product inflation of the substitution of domestically produced goods with LWC imports. "Contribution" is the substitution channel effect multiplied by the share of the COICOP in CPI consumption. 
Table 3: Contribution of LWC Imports to Import Price Inflation: an International Comparison

\begin{tabular}{lccc}
\hline Country & Period & $\begin{array}{c}\text { Impact of LWC imports } \\
\text { on import inflation }\end{array}$ & Source \\
\hline France & $1995-2005$ & $-0.48 \mathrm{pp}$ & This study \\
Austria & $1995-2005$ & $-0.66 \mathrm{pp}$ & Glatzer et al. [2006] \\
$\begin{array}{l}\text { Finland } \\
\text { Portugal }\end{array}$ & $1996-2005$ & $-1 \mathrm{pp}$ & Bank of Finland [2006 \\
$\begin{array}{l}\text { Sweden } \\
\text { United States }\end{array}$ & $1998-2006$ & $-0.2 \mathrm{pp}$ & Cardoso and Esteves [2008] \\
& $1996-2004$ & -1 to $-2 \mathrm{pp}$ & Sveriges Riksbank [2005] \\
\hline $\begin{array}{l}\text { France } \\
\text { United Kingdom }\end{array}$ & $2000-2002$ & -0.8 to $-1 \mathrm{pp}$ & Kamin et al. [2006] \\
& $2000-2005$ & $-0.7 \mathrm{pp}$ & This study \\
\hline
\end{tabular}

Note: this table reports estimates of the contribution of LWC imports to import price inflation in different countries. These estimates are obtained using a very similar methodology presented in section 2 and correspond to our "imported inflation effect" (Channel 2). Differences in methodologies may come from the definitions of country categories and also from the level of product disaggregation. Results presented for France are calculated over two different periods (1995-2005) and (2000-2005) to facilitate cross country comparisons. 
Table 4: Imported Inflation Channel - Decomposition by COICOP Product Categories (average, 1994-2014)

\begin{tabular}{|c|c|c|c|c|c|}
\hline $\begin{array}{l}\text { COICOP } \\
(\% \text { of } \mathrm{CPI})\end{array}$ & $\begin{array}{l}\text { Imports } \\
\text { pen. } \\
\beta \eta\end{array}$ & $\begin{array}{c}\text { Imported in } \\
\text { Switching } \\
\frac{\partial \gamma_{t}}{\partial t}\left(p^{L W C}-p^{H W C}\right)\end{array}$ & $\begin{array}{l}\text { Hation effect } \\
\text { Infl. diff. } \\
\gamma\left(\pi^{L W C}-\pi^{H W C}\right)\end{array}$ & $\begin{array}{l}\text { Channel } \\
2\end{array}$ & $\begin{array}{l}\text { Contrib. to } \\
\text { CPI infl. } \\
\text { in pp }\left(\times 10^{2}\right)\end{array}$ \\
\hline $\begin{array}{l}\text { 1- Food and non-alcohol. } \\
\text { beverages }(15 \%)\end{array}$ & 0.11 & -0.06 & -0.01 & -0.01 & -0.12 \\
\hline $\begin{array}{l}2-\text { Alcoholic beverages } \\
\text { and tobacco }(4 \%)\end{array}$ & 0.14 & -0.08 & 0.00 & -0.01 & -0.05 \\
\hline $\begin{array}{l}\text { 3- Clothing and } \\
\text { footwear }(4 \%)\end{array}$ & 0.57 & -0.63 & 0.24 & -0.22 & -0.89 \\
\hline $\begin{array}{l}\text { 4- Housing, water, elect., } \\
\text { gas... }(14 \%)\end{array}$ & 0.37 & -0.27 & 0.07 & -0.07 & -1.05 \\
\hline $\begin{array}{l}5 \text { - Furnishings, house } \\
\text { services }(6 \%)\end{array}$ & 0.53 & -0.63 & 0.07 & -0.29 & -1.76 \\
\hline 6- Health $(10 \%)$ & 0.15 & -0.34 & 0.03 & -0.04 & -0.45 \\
\hline 7- Transport (16\%) & 0.23 & -0.43 & 0.05 & -0.09 & -1.38 \\
\hline 8- Communication (3\%) & 0.56 & -0.01 & 1.20 & 0.66 & 1.98 \\
\hline $\begin{array}{l}\text { 9- Recreation and } \\
\text { culture }(8 \%)\end{array}$ & 0.40 & -0.64 & 0.04 & -0.24 & -1.90 \\
\hline $\begin{array}{l}\text { 11- Restaurants } \\
\text { and hotels }(8 \%)\end{array}$ & 0 & - & - & - & 0.0 \\
\hline $\begin{array}{l}\text { 12- Miscellaneous } \\
\text { goods and services }(13 \%)\end{array}$ & 0.24 & -0.45 & 0.078 & -0.09 & -1.15 \\
\hline
\end{tabular}

Note: The first column "Import pen." reports import penetration by COICOP aggregate category as the share of total imports (source: Customs) in the product category consumption (source: Insee, national accounts) (including VAT and distribution margins). Second and third column report the contribution of LWC imports to the product-level import inflation (following the decomposition presented in equation ??). Column 2 reports results for the switching effect (i.e consumers switching from HWC imports to LWC imports) whereas col. 3 reports results of inflation differential (i.e. HWC import prices growing more or less quickly than LWC import prices). Column 4 reports the estimation of the contribution of LWC import to CPI inflation coming from the Imported inflation effect (Channel $2)$, calculated as col.(1) $\times(\mathrm{col} .(2)+\operatorname{col} .(3))$. "Contribution" is the channel 2 effect multiplied by the share of the COICOP in CPI consumption. 
Table 5: Impact of LWC Imports on French Producer Price Inflation

\begin{tabular}{lcccccc}
\hline & \multicolumn{2}{c}{ All goods } & \multicolumn{2}{c}{ Consumption goods } & \multicolumn{2}{c}{$\begin{array}{c}\text { High Import } \\
\text { penetration }\end{array}$} \\
& OLS & IV & OLS & IV & OLS & IV \\
& & & & & & \\
\hline & & & & & & \\
$\Delta$ share - LWC & $0.134^{*}$ & $-1.208^{* *}$ & $0.198^{*}$ & -0.803 & 0.102 & -1.656 \\
& $(0.063)$ & $(0.615)$ & $(0.103)$ & $(1.283)$ & $(0.086)$ & $(1.312)$ \\
$\Delta$ Interm. Input costs & $0.226^{* * *}$ & $0.249^{* * *}$ & $0.095^{* *}$ & $0.100^{*}$ & $0.245^{* * *}$ & $0.340^{* * *}$ \\
& $(0.041)$ & $(0.044)$ & $(0.048)$ & $(0.051)$ & $(0.058)$ & $(0.103)$ \\
$\Delta$ Labour costs & -0.052 & 0.025 & -0.069 & 0.004 & -0.043 & 0.145 \\
& $(0.044)$ & $(0.054)$ & $(0.080)$ & $(0.077)$ & $(0.068)$ & $(0.140)$ \\
Cragg-Donald statistic & - & 24.79 & - & 8.38 & - & 6.66 \\
Stock-Yogo crit. value & - & $10 \%$ & - & $20 \%$ & - & $20 \%$ \\
F-stat. 1st stage & - & 18.22 & - & 3.64 & - & 4.43 \\
$R^{2}$ & 0.11 & 0.03 & 0.14 & 0.06 & 0.11 & 0.06 \\
Nb products & 154 & 154 & 52 & 52 & 81 & 81 \\
Nb observations & 1,986 & 1,981 & 699 & 699 & 984 & 981 \\
& & & & & & \\
\hline
\end{tabular}

Note: this table reports estimates of OLS and IV regressions where the dependent variable is the annual PPI inflation calculated as the annual change in producer price index (domestic market) for 154 products defined at level 4 of the NACE rev2 classification (manufacturing industries only) (source: Insee) on the period 1995-2014 (when available). Product and year dummies are included in all specifications. Robust standard errors are reported in brackets. " $\Delta$ share" is the annual change in the share of LWC's imports in total French imports and domestic production. Year (19 years) and product (154 products) dummies are included, controls for annual growth rate of intermediate input costs and labour costs at the sectoral level (level 2 of NACE classification, source: Stan OECD) are also included. "All goods" include all goods for which producer price inflation is available, "Consumption goods", include goods that can be match with CPI classification, "High import penetration"' include goods for which the import penetration is higher than the average (about 33\%). Columns (1), (3), and (5) correspond to results obtained from OLS regressions, all other columns report results of IV regressions where the instrumental variable is the sector's labor share multiplied by the annual growth rate of LWC exports (see Appendix C for details and results of first-stage regressions). 
Table 6: Impact of Chinese Imports on French Producer Price Inflation

\begin{tabular}{lcccccc}
\hline & \multicolumn{2}{c}{ All goods } & \multicolumn{2}{c}{ Consumption goods } & \multicolumn{2}{c}{$\begin{array}{c}\text { High Import } \\
\text { penetration }\end{array}$} \\
& OLS & IV & OLS & IV & OLS & IV \\
& & & & & & \\
\hline \multirow{3}{*}{ share - China } & -0.043 & $-1.846^{*}$ & 0.122 & -1.124 & -0.067 & -1.550 \\
& $(0.082)$ & $(0.990)$ & $(0.116)$ & $(1.555)$ & $(0.087)$ & $(1.110)$ \\
$\Delta$ Interm. Input costs & $0.228^{* * *}$ & $0.224^{* * *}$ & $0.095^{* *}$ & $0.093^{*}$ & $0.251^{* * *}$ & $0.254^{* * *}$ \\
& $(0.041)$ & $(0.039)$ & $(0.047)$ & $(0.049)$ & $(0.057)$ & $(0.055)$ \\
$\Delta$ Labour costs & -0.043 & -0.010 & -0.059 & -0.013 & -0.028 & 0.032 \\
& $(0.044)$ & $(0.047)$ & $(0.080)$ & $(0.083)$ & $(0.068)$ & $(0.075)$ \\
Cragg-Donald statistic & - & 25.56 & - & 4.98 & - & 13.13 \\
Stock-Yogo crit. value & - & $10 \%$ & - & $>25 \%$ & - & $15 \%$ \\
F-stat. 1st stage & - & 15.71 & - & 2.83 & - & 9.37 \\
$R^{2}$ & 0.11 & 0.04 & 0.14 & 0.07 & 0.11 & 0.04 \\
Nb products & 154 & 154 & 52 & 52 & 81 & 81 \\
Nb observations & 1,986 & 1,981 & 699 & 699 & 984 & 981 \\
& & & & & & \\
\hline
\end{tabular}

Note: this table reports estimates of OLS and IV regressions where the dependent variable is the annual PPI inflation calculated as the annual change in producer price index (domestic market) for 154 products defined at level 4 of the NACE rev2 classification (manufacturing industries only) (source: Insee) on the period 1995-2014 (when available). Product and year dummies are included in all specifications. Robust standard errors are reported in brackets. " $\Delta$ share" is the annual change in the share of China's imports in total French imports and domestic production. Year (19 years) and product (154 products) dummies are included, controls for annual growth rate of intermediate input costs and labour costs at the sectoral level (level 2 of NACE classification, source: Stan OECD) are also included. "All goods" include all goods for which producer price inflation is available, "Consumption goods", include goods that can be match with CPI classification (a little more than 50 products), "High import penetration"' include goods for which the import penetration is higher than the average (about 33\%). Columns (1), (3), and (5) correspond to results obtained from OLS regressions, all other columns report results of IV regressions where the instrumental variable is the sector's labor share multiplied by the annual growth rate of Chinese exports (see Appendix C for details and results of first-stage regressions). 
Table 7: Average values of main variables (1994-2014)

Channel 1: Substitution

$\begin{array}{lccccc} & \beta & \frac{\partial \eta_{t}}{\partial t} & \gamma & \left(p_{t}^{L W C}-p_{t}^{d}\right) & \text { Contrib CPI } \\ \text { LWC } & 0.46 & 0.81 & 0.31 & -0.41 & -0.05 \\ \text { China } & 0.46 & 0.81 & 0.13 & -0.52 & -0.03\end{array}$

Channel 2: Imported Inflation
$\beta \eta$
$\frac{\partial \gamma_{t}}{\partial t}\left(p^{L W C}-p^{H W C}\right) \quad \gamma\left(\pi^{L W C}-\pi^{H W C}\right)$
$(1)+(2)$
Contrib CPI

LWC

0.14

(1)

(2)

China

0.14

$-0.47$

0.06

$-0.41$

$-0.06$

$-0.39$

0.06

$-0.33$

$-0.05$

Channel 3: Competition

$\begin{array}{lcccc} & \beta \times(1-\eta) & \frac{\partial S_{t}^{L W C}}{\partial t} & \frac{\partial \pi_{t}}{\partial S_{t}^{L W C}} & \text { Contrib CPI } \\ \text { LWC } & 0.32 & 0.17 & -1.21 & -0.06 \\ \text { China } & 0.32 & 0.05 & -1.85 & -0.02\end{array}$

Note: The table presents the values of the main variables used in the analysis. Each variable is first calculated yearly, and then averaged over the period 1994-2014. In the case of variable denoting changes over time (i.e. $\frac{\partial \eta_{t}}{\partial t}$ ), first the year-on-year percentage change is calculated and average over the period. "Contrib CPI" is the total contribution of each channel to the evolution of French CPI inflation. Details of the variables' construction are provided in sections 2 and 4 . 
Figure 1: French CPI Inflation: Tradables versus Non Tradables

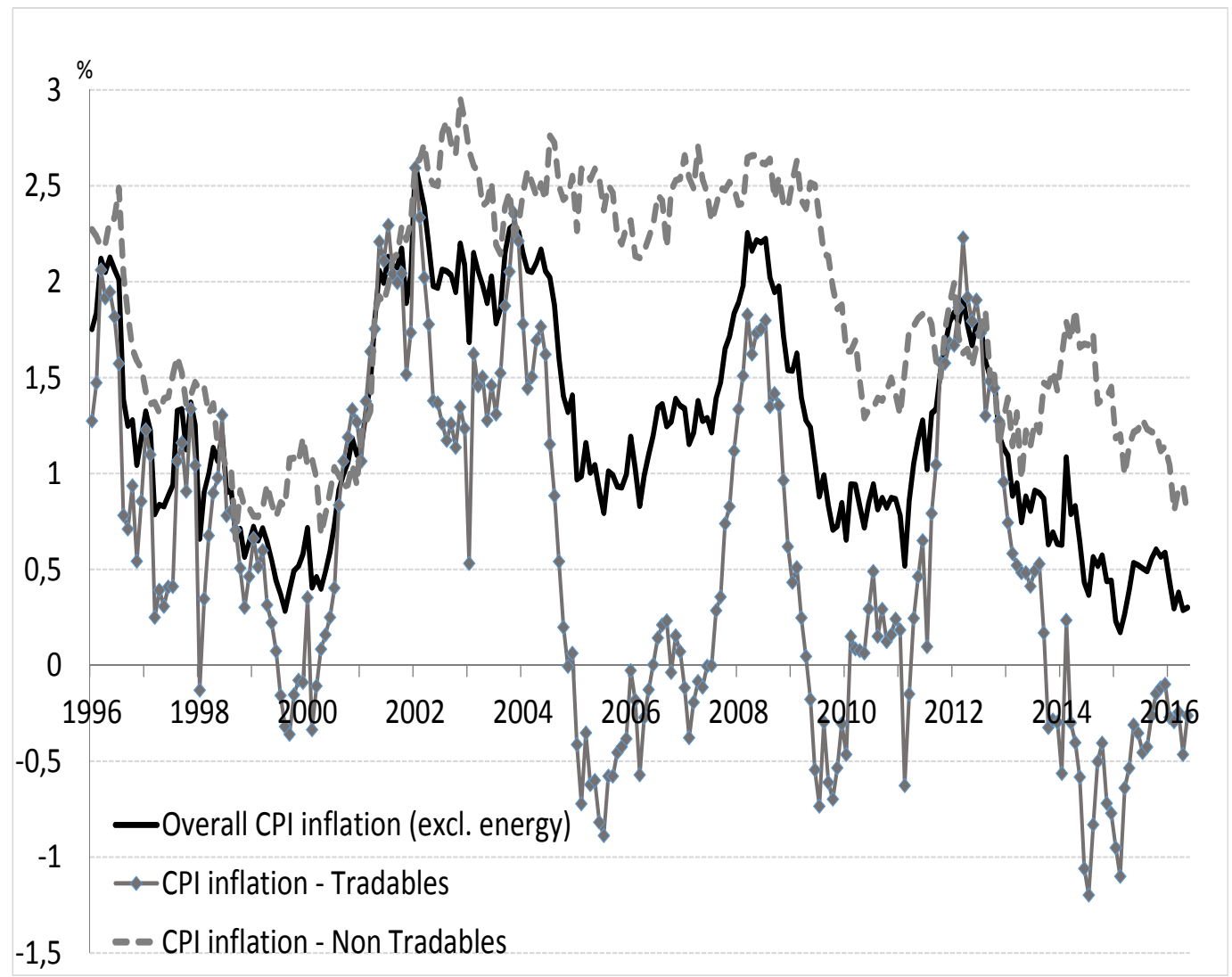

Note: the figure plots in black the French CPI inflation (excluding energy). The dashed grey line is the inflation rate for non tradables. The thin grey line with squares is the tradables inflation. At the most disaggregate COICOP level available, we define a COICOP category being part of tradables if the share of imports in consumption is not equal to 0 . 
Figure 2: Import Price Inflation - A Comparison

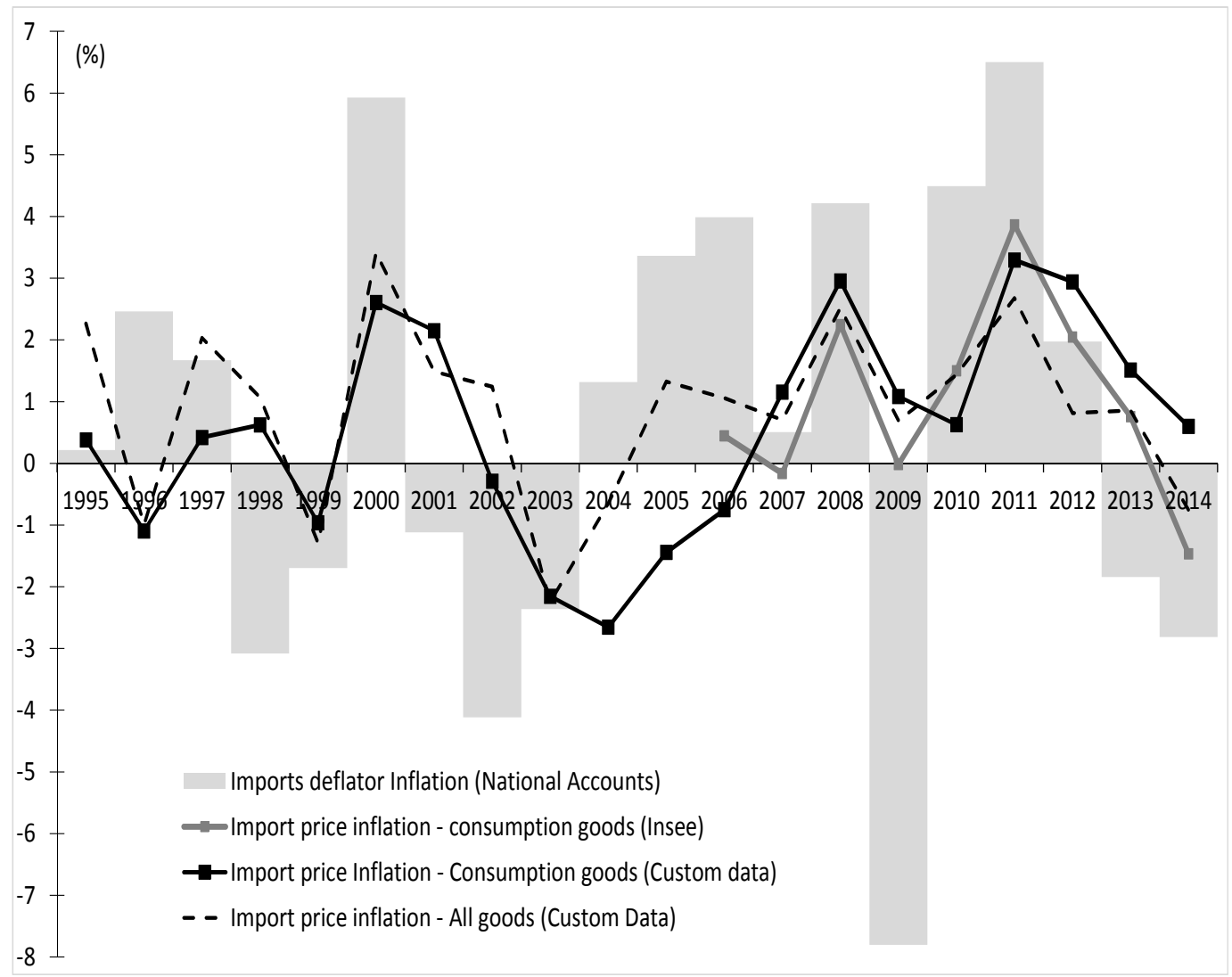

Note: the figure plots in dark grey line the annual variation of import price inflation for industrial goods (source: Insee - aggregate monthly series of import price index), in grey histogram the annual variation of the import deflator for manufactured goods including mining and quarrying (source Insee annual national accounts) and in black lines, annual variations of our import price index computed using trade unit values and price indices by product and country categories (see section 3.2 ). The black dashed line corresponds to import inflation including all goods whereas the black line corresponds to import inflation only for consumption goods. 
Figure 3: Import Penetration (1994-2014)

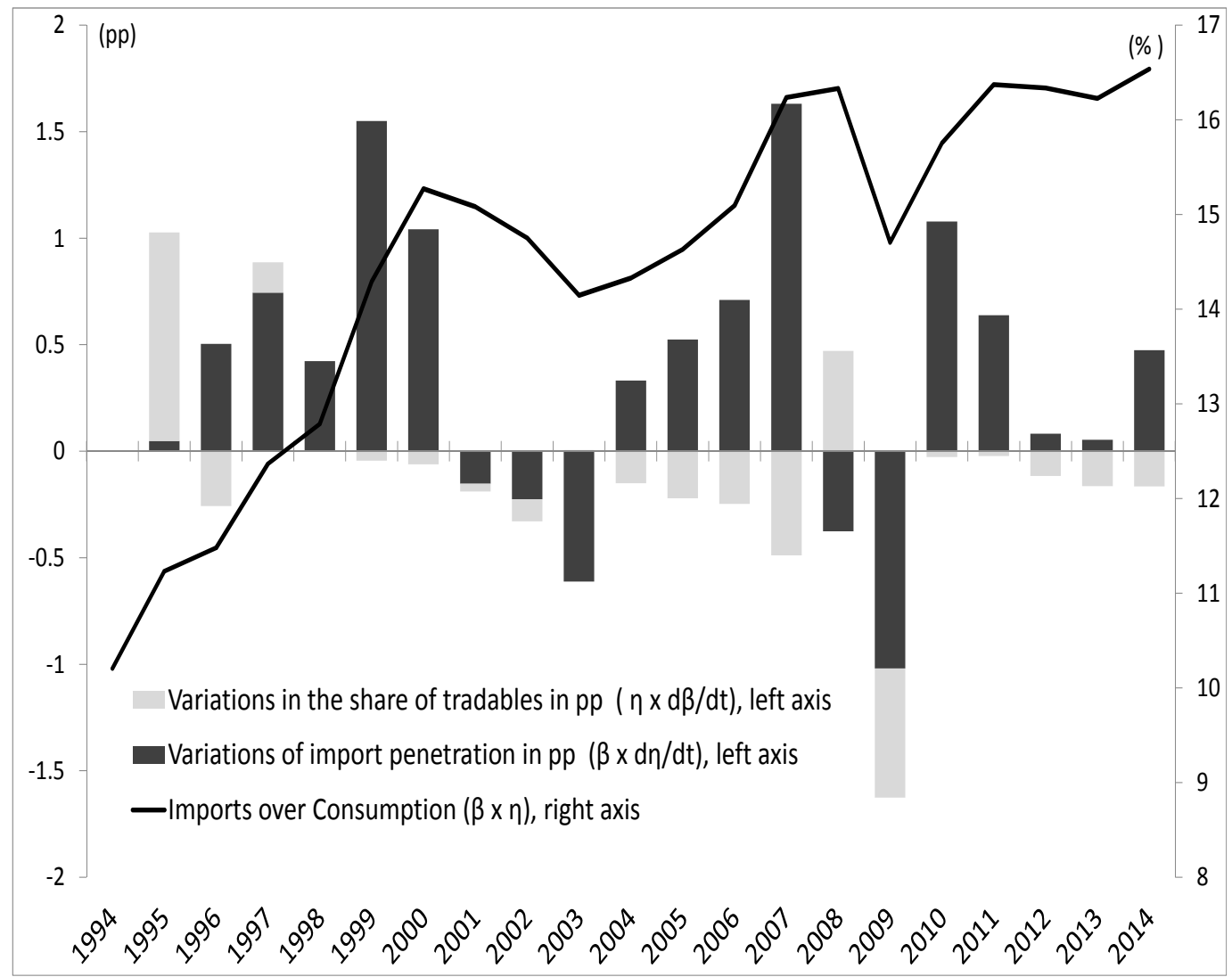

Note: this figure plots the share of imports in total CPI consumption by year (RHS scale, in percentage). Grey histograms The yearly change in import penetration (i.e. the yearly change in the back dashed line) is the sum of both histograms (LHS scale) in a given year. The plain grey histogram plots the changes in total import penetration $\left(\eta_{t}\right)$ weighted by the share of tradable goods in consumption and the share of LWCs in imports. Once this term is multiplied by the price difference $\left(p_{t}^{L W C}-p_{t}^{d}\right)$, we get exactly the channel 1 . The dashed grey histogram represents the contribution of changes in $\beta_{t}$ to yearly changes in import penetration from LWCs. 
Figure 4: Price of Domestically Produced Goods Relative to Prices of Imported Goods (Consumer Goods)

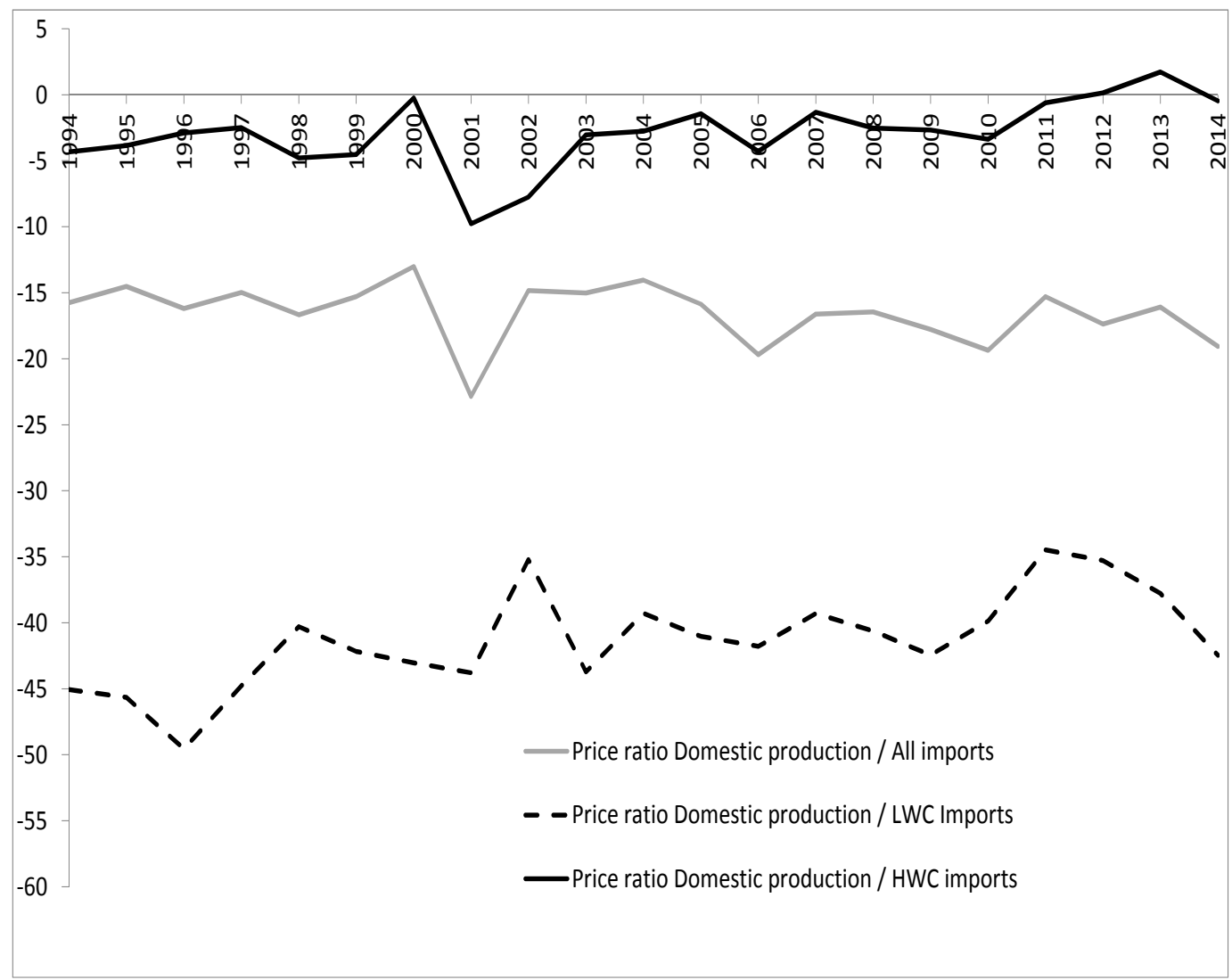

Note: We first compute the price differential (in a given year) at the level 8 of the trade product classification (HS classification) between import unit values and export unit values (considered as equivalent to the domestic producer price). The figure reports the weighted average of this price differential. The black line corresponds to the price differential between HWC imports and French export prices, the grey line corresponds to the average using price differential between imports of all origins and French exports prices, the dashed black line corresponds to the average price differential between LWC imports and French exports prices. 
Figure 5: Share of imports in consumption by COICOP category

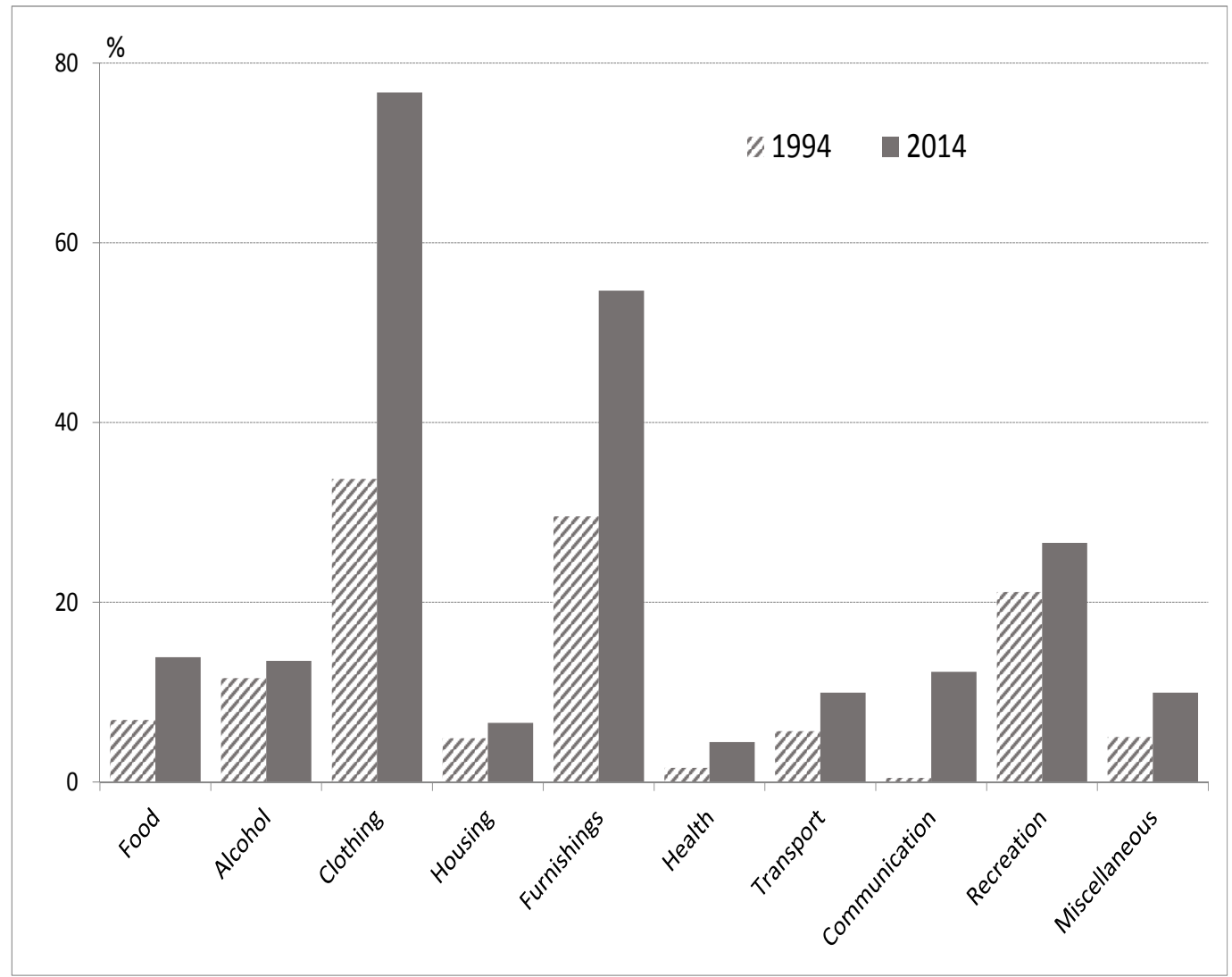

Note: "\% of imports in consumption" reports for each COICOP aggregate category the ratio between total imports of a given product (source: Customs) and the total French consumption (source: Insee, national accounts) (including VAT and distribution margins). 
Figure 6: Import Market Shares over Time and by Country Category

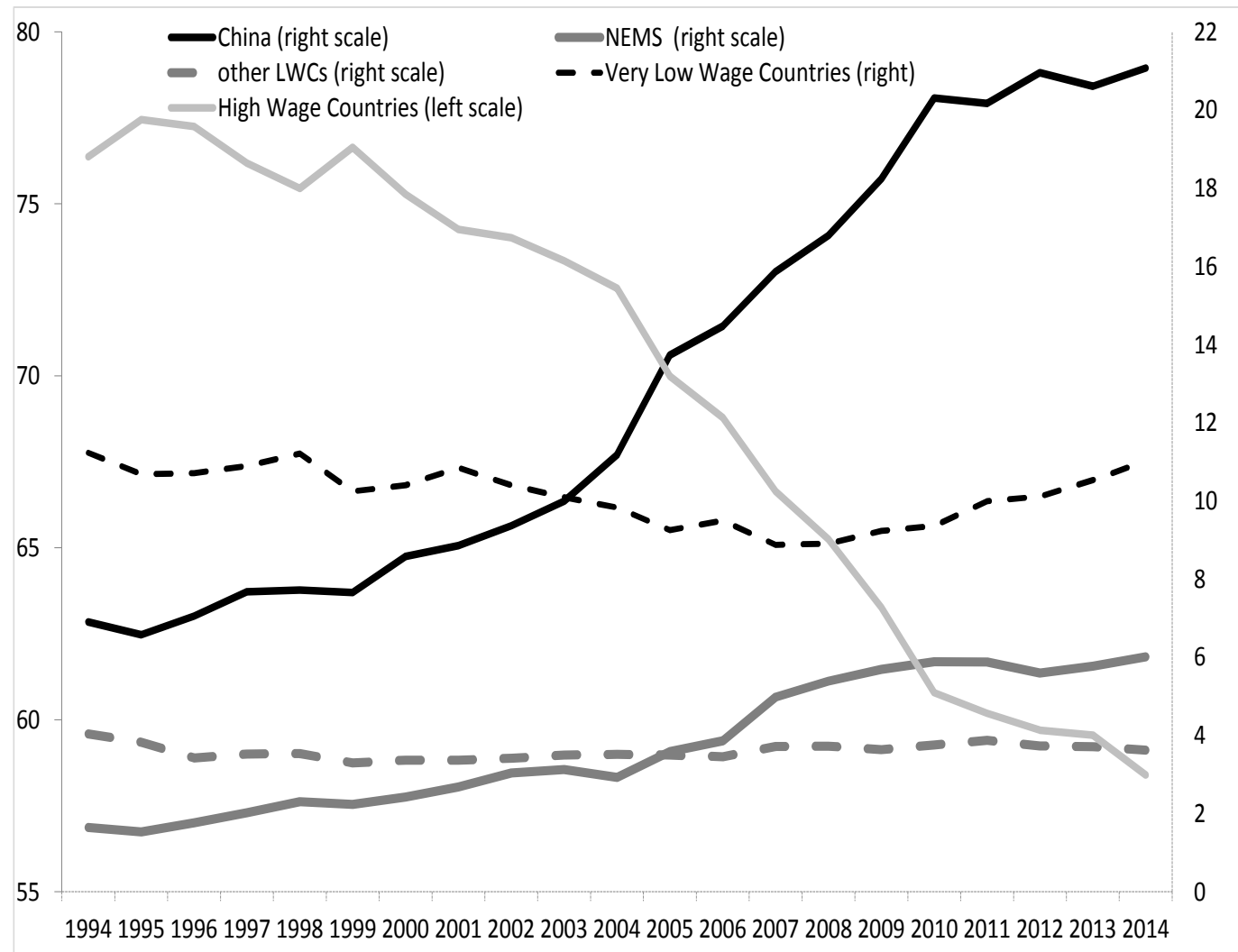

Note: the figure plots the ratio of imports value coming from a given country category over all French imports (in percent), these ratios are computed for the five country categories (see Table 1). The grey line plots the share of high wage countries imports in all French imports (left axis), the black line plots the share of Chinese imports in all French imports (right axis), the dashed black line plots the share of very low wage countries imports in all French imports (right axis), the dark grey line plots the share of NEUMS countries imports in all French imports (right axis) and the dashed dark grey line plots the share of low wage countries imports in all French imports (right axis). 
Figure 7: Import Price Inflation Differential: High-wage vs. Low-wage Countries

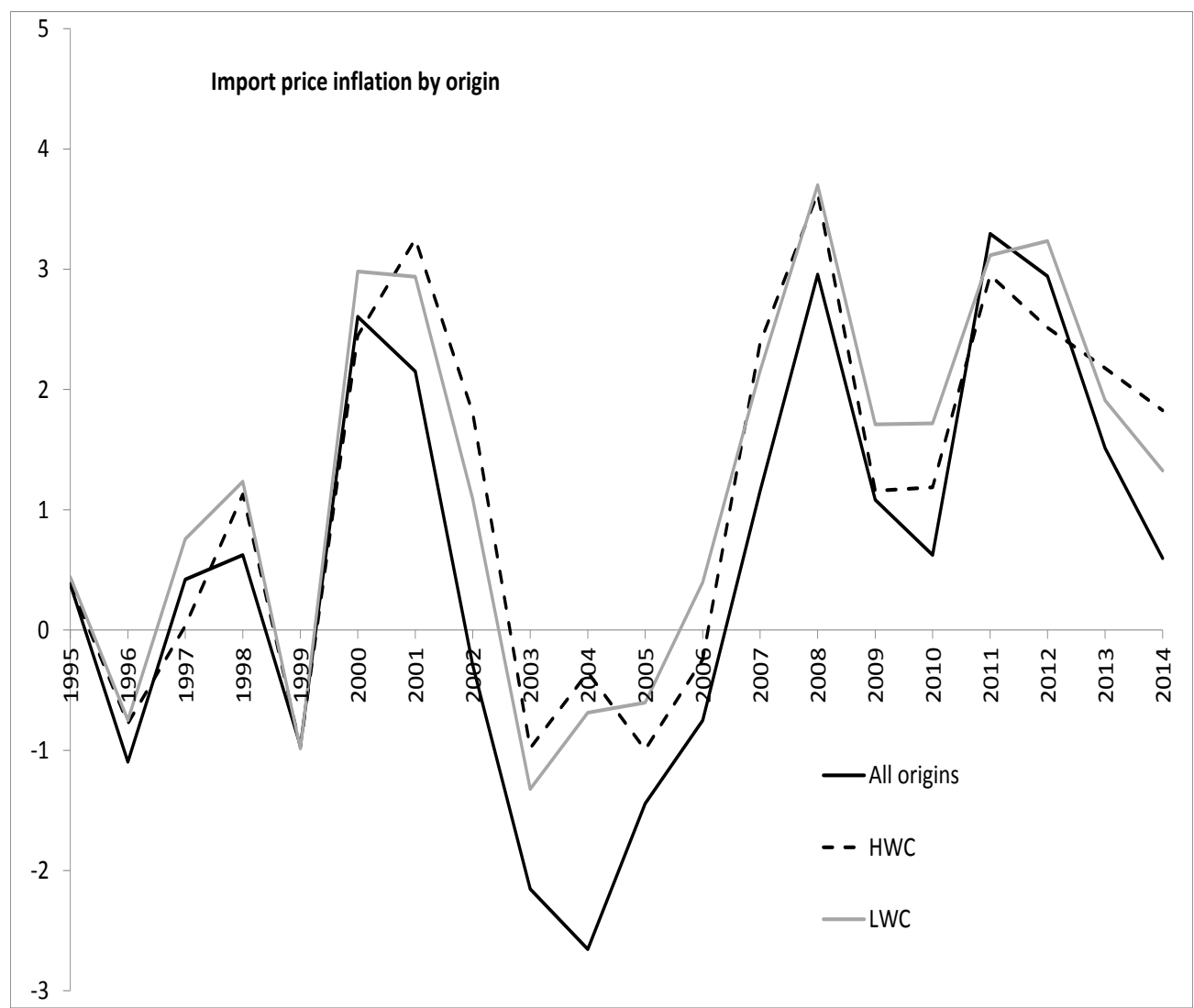

Note: the figure plots the y-o-y inflation rate of two components of the overall French import price inflation (the solid black line). The solid light-grey line is the import price inflation for goods produced in LWCs while the dashed black line corresponds to goods imported from HWCs. Note that overall import price inflation might be lower than the weighted average of the two components because a switching effect is also at play, and the weight of LWCs (with lower import prices in level) increase to the detriment of HWCs. 
Figure 8: Contribution to Import Price Inflation: Substitution vs Inflation Differential Effects

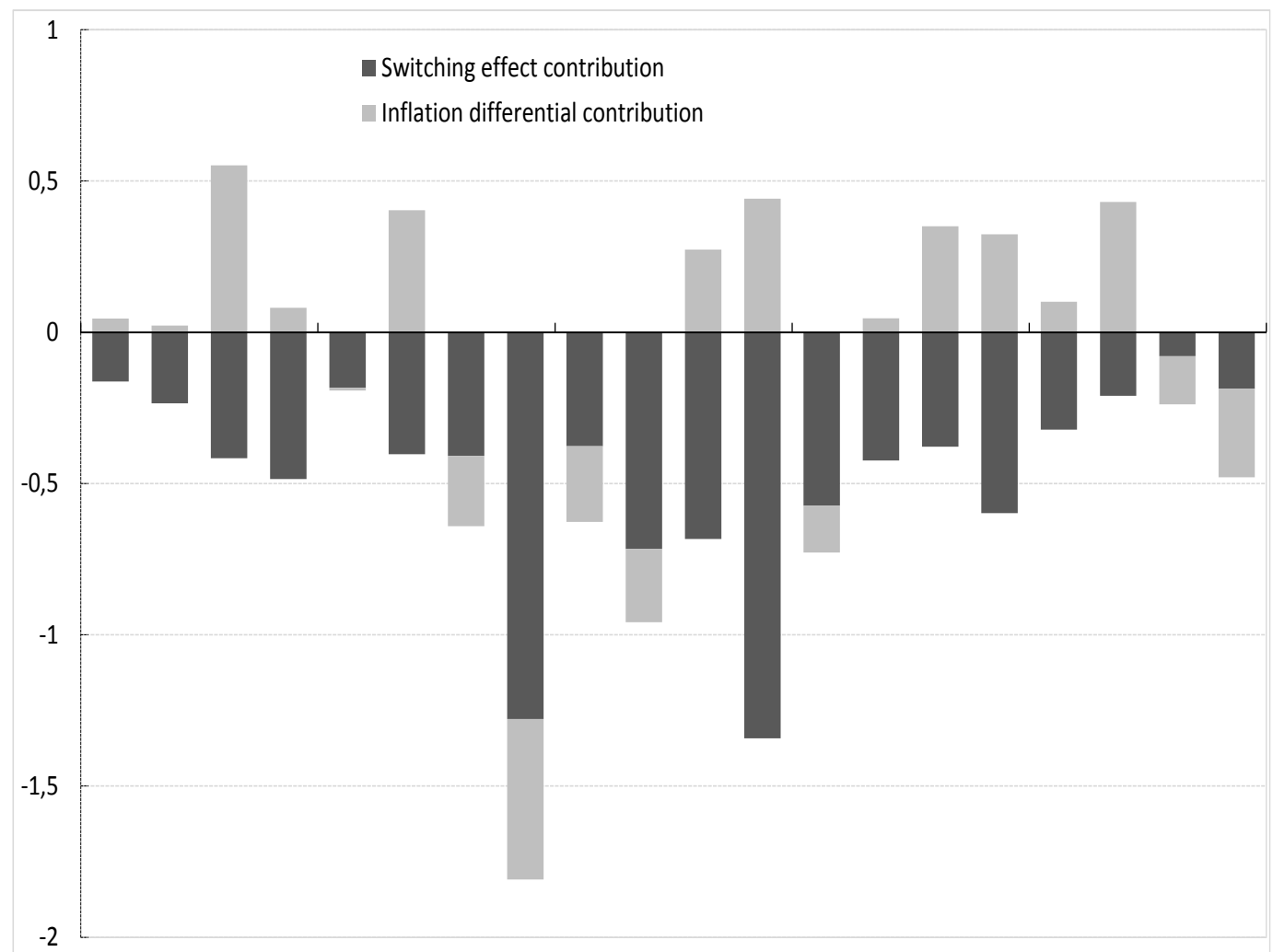

19951996199719981999200020012002200320042005200620072008200920102011201220132014

Note: We first calculate for each year and each product (restricting to consumer goods) the impact of LWC imports on import price inflation. We distinguish the impact coming from a variation of the share of LWC imports in total imports (called Switching effect) and the impact coming from differences in inflation between LWC and HWC imports (called Inflation Differential effect). The figure plots the weighted average contribution of LWC imports on French import inflation and distinguish between substitution (black histogram) and inflation differential (grey histogram) contributions. The overall impact of LWC imports on French import inflation is obtained as the sum of both histograms in a given year. 
Figure 9: Substitution Contribution to Import Inflation: Country Category Decomposition

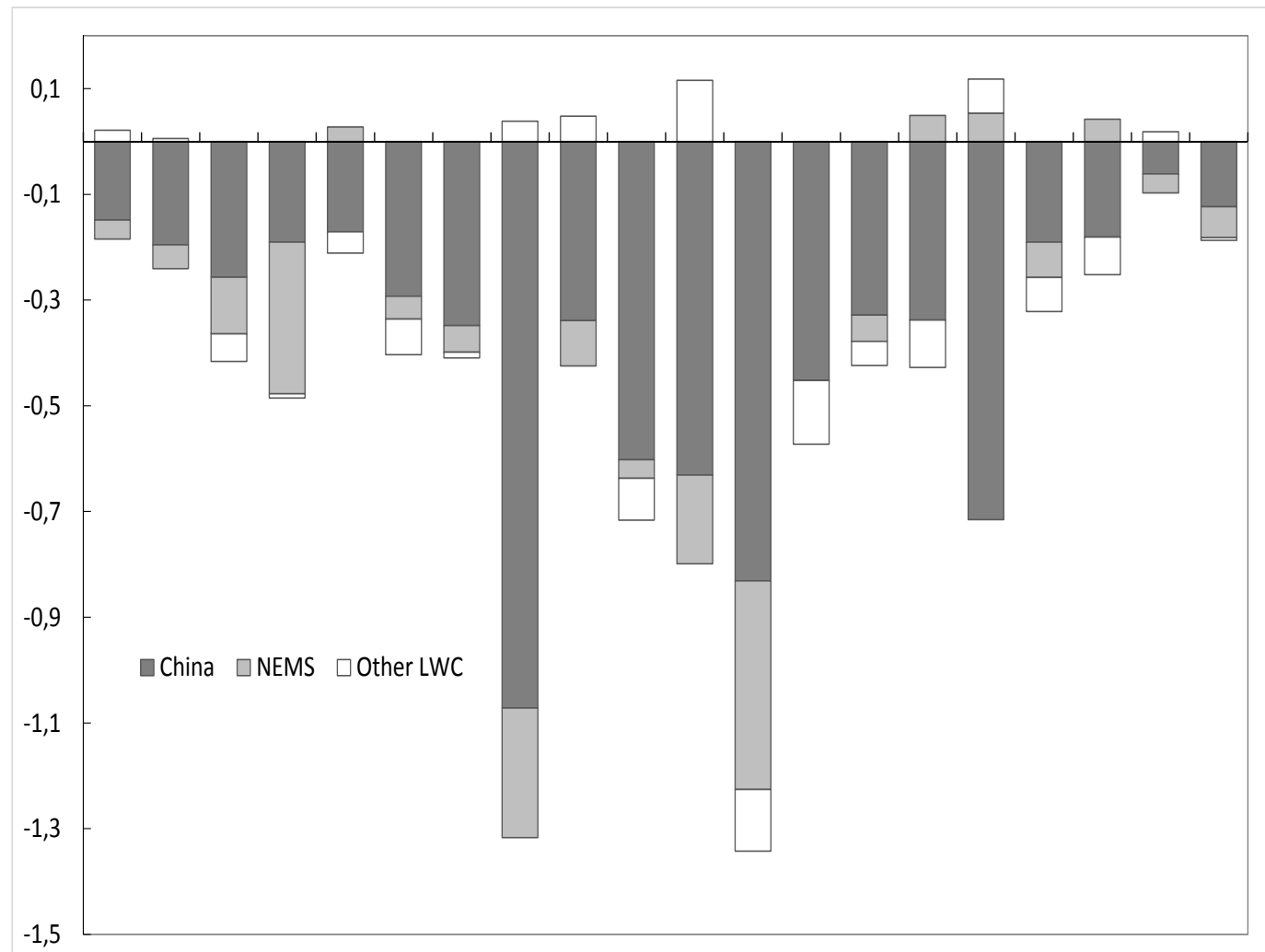

19951996199719981999200020012002200320042005200620072008200920102011201220132014

Note: we first calculate the contribution of LWC imports due to variations in the share of LWC imports in total imports by country category. The figure plots the weighted average contribution of LWC imports on French import inflation due to substitution effect by country category. The dark grey histogram plots the substitution contribution due to the Chinese imports, the light grey histogram plots the substitution contribution due to NEUMS imports, the white histogram plots the substitution contribution due to all other LWC imports (obtained as the sum of the substitution effect due the other LWC imports and other VLWC imports). The overall substitution effect of LWC imports on French import inflation is obtained as the sum of all three histograms in a given year. 


\section{APPENDIX - Intended for Online Publication}

\section{A Inflation Decomposition}

We provide details of the derivation of equation (11). Deriving equation (1) with respect to time and rearranging terms:

$$
\frac{\partial p_{t}}{\partial t}=\frac{\partial p_{t}^{N T}}{\partial t}+\beta_{t}\left(\frac{\partial p_{t}^{T}}{\partial t}-\frac{\partial p_{t}^{N T}}{\partial t}\right)+\frac{\partial \beta_{t}}{\partial t}\left(p_{t}^{T}-p_{t}^{N T}\right)
$$

Inflation at any given year $t$ is the rate of inflation of non-tradables, plus (a) the inflation differential between tradable and non-tradable goods (for a given share of tradable in consumption) and (b) the change in the consumption share of tradables, holding price-level differentials fixed.

The same decomposition can be applied to the price index of tradable goods (equation (2) and the price index of imported goods (equation (3)):

$$
\begin{aligned}
& \frac{\partial p_{t}^{T}}{\partial t}=\eta_{t}\left(\frac{\partial p_{t}^{F}}{\partial t}-\frac{\partial p_{t}^{D}}{\partial t}\right)+\frac{\partial \eta_{t}}{\partial t}\left(p_{t}^{F}-p_{t}^{D}\right)+\frac{\partial p_{t}^{D}}{\partial t} \\
& \frac{\partial p_{t}^{F}}{\partial t}=\gamma_{t}\left(\frac{\partial p_{t}^{L}}{\partial t}-\frac{\partial p_{t}^{H}}{\partial t}\right)+\frac{\partial \gamma_{t}}{\partial t}\left(p_{t}^{L}-p_{t}^{H}\right)+\frac{\partial p_{t}^{H}}{\partial t}
\end{aligned}
$$

Inserting equations (8) and (9) into equation (7):

$$
\begin{aligned}
\frac{\partial p_{t}^{T}}{\partial t} & =\beta_{t}\left\{\eta_{t}\left[\gamma_{t}\left(\frac{\partial p_{t}^{L}}{\partial t}-\frac{\partial p_{t}^{H}}{\partial t}\right)+\frac{\partial \gamma_{t}}{\partial t}\left(p_{t}^{L}-p_{t}^{H}\right)+\frac{\partial p_{t}^{H}}{\partial t}-\frac{\partial p_{t}^{D}}{\partial t}\right]\right. \\
& \left.+\frac{\partial \eta_{t}}{\partial t}\left[\gamma_{t} p_{t}^{L W C}+\left(1-\gamma_{t}\right) p_{t}^{H W C}-p_{t}^{D}\right]+\frac{\partial p_{t}^{D}}{\partial t}\right\} \\
& -\beta_{t} \frac{\partial p_{t}^{N T}}{\partial t}+\frac{\partial \beta_{t}}{\partial t}\left[\eta_{t} p_{t}^{f}+\left(1-\eta_{t}\right) p_{t}^{D}-p_{t}^{N T}\right]+\frac{\partial p_{t}^{N T}}{\partial t}
\end{aligned}
$$

Collecting terms and using $\pi_{t}=\frac{\partial p_{t}}{\partial t}$ to denote percentage cahnges in prices $\left(p_{t}^{T}, p_{t}^{D}, p_{t}^{H W C}, p_{t}^{L W C}\right)$ and $\left(\dot{x}_{t}=\partial x_{t} / \partial t\right)$ to denote percentage changes in the share variables $x_{t}=\left(\beta_{t}, \eta_{t} ; \gamma_{t}\right)$ we 
get expression (11) in the main text.

In the case of discrete time, a first-order approximation gives an expression which is equivalent to (11) in the main text. Defining, for a variable $x, \Delta x_{t}=x_{t}-x_{t-1}$ :

$$
\begin{aligned}
\Delta p_{t} & =\underbrace{\beta_{t} \Delta \eta_{t} \gamma_{t}\left(p_{t}^{L W C}-p_{t}^{D}\right)}_{\text {Substitution Channel }} \\
& +\underbrace{\beta_{t} \eta_{t} \Delta \gamma_{t}\left(p_{t}^{L W C}-p_{t}^{H W C}\right)+\beta_{t} \eta_{t} \gamma_{t}\left(\Delta p_{t}^{L W C}-\Delta p_{t}^{H W C}\right)}_{\text {Imported Inflation Channel }} \\
& +\underbrace{\beta_{t}\left(1-\eta_{t}\right) \Delta p_{t}^{d}}_{\text {Competition Channel }}+\beta_{t}\left[\eta_{t} \Delta p_{t}^{H W C}+\left(1-\gamma_{t}\right) \frac{\partial \eta_{t}}{\partial t}\left(p_{t}^{H W C}-p_{t}^{D}\right)\right]+\left(1-\beta_{t}\right) \Delta p_{t}^{N T}+\Delta \beta_{t}\left(p_{t}^{T}-p_{t}^{N T}\right)
\end{aligned}
$$




\section{B Model}

This section builds a simple model of oligopolistic competition at the sector level (à la Atkeson and Burstein [2008]), that generates complementarities in price setting, from which we derive equation (6). Specifically, we suppose there are only three firms within each sector: one domestic and two foreign competitors, one from LWCs and one from HWCs. Since firms are not atomistic within a sector, strategic behaviors arise and the domestic producer adjusts its price in response to changes in the market shares of its foreign competitors.

Turning to the details of the model, we assume that the final consumption good is the Dixit-Stiglitz aggregation of imperfect substitutable products, denoted by $i$. There are two layers of production:

1. The final consumption good, denoted $Y_{t}$, is composed of differentiated products supplied by a continuum of sectors (indexed by $i$ ) on $[0,1]: Y_{t}=\left[\int_{0}^{1} Y_{t}(i)^{\frac{\sigma-1}{\sigma}} d k\right]^{\frac{\sigma}{\sigma-1}}$, where $\sigma$ is the elasticity of substitution between products from different sectors. The demand for sectoral good is $Y_{t}(i)=\left(\frac{P_{t}(i)}{P_{t}}\right)^{-\sigma} Y_{t}$, where $P_{t}$ is the consumption price index defined as $P_{t}=\left[\int_{0}^{1} P_{t}(i)^{1-\sigma} d k\right]^{\frac{1}{1-\sigma}}$ and $P_{t}(i)$ is the sectoral price. Here sector $i$ is the market for a product typically defined at a very detailed product level (8-digit in our empirical analysis).

2. In each sector, the sectoral good $i$ is produced by a retailer that combines two intermediate goods (supplied by one domestic and one foreign firm): $Y_{t}(i)=$ $\left[\sum_{j} x_{t}(j, i)^{\frac{\theta-1}{\theta}}\right]^{\frac{\theta}{\theta-1}}$ with $j \in\{D, F\}$. The associated price index is $P_{t}(i)=\left[\sum_{j} P_{t}(j, i)^{1-\theta}\right]^{\frac{1}{1-\theta}}$.

The demand for good $j$ in sector $i$ is:

$$
x_{t}(j, i)=\left(\frac{P_{t}(j, i)}{P_{t}(i)}\right)^{-\theta} Y_{t}(i)=\left(\frac{P_{t}(j, i)}{P_{t}(i)}\right)^{-\theta}\left(\frac{P_{t}(i)}{P_{t}}\right)^{-\sigma} Y_{t}
$$


The elasticity of substitution between goods within a sector is greater than the elasticity of substitution across sectors $(\theta>\sigma)$.

Consider the behavior of a firm $j$ within a given manufacturing industry $i$. Under Bertrand oligopolistic competition, the perceived elasticity of demand to a firm's own price, $\Theta_{t}(j, i)$, is not constant, although the elasticity of substitution between goods in the sector is constant $(\theta)$.

$$
\Theta_{t}(j, i)=-\frac{\partial x_{t}(j, i)}{\partial P_{t}(j, i)} \frac{P_{t}(j, i)}{x_{t}(j, i)}=\theta-(\theta-\sigma) \underbrace{\left(\frac{\partial P_{t}(i)}{\partial P_{t}(j, i)} \frac{P_{t}(j, i)}{P_{t}(i)}\right)}_{=\left(\frac{P_{t}(j, i)}{P_{t}(i)}\right)^{1-\theta} \neq 0}
$$

The profit maximization problem of firm $j$ at time $t$ given the cost function $\mathcal{C}(\dot{)}$ is:

$$
\begin{aligned}
& \max _{P_{t}(j, i)} P_{t}(j, i) x_{t}(j, i)-\mathcal{C}\left(x_{t}(j, i)\right) \\
& \text { s.t. } x_{t}(j, i)=\left(\frac{P_{t}(j, i)}{P_{t}(i)}\right)^{-\theta}\left(\frac{P_{t}(i)}{P_{t}}\right)^{-\sigma} Y_{t}
\end{aligned}
$$

The first order condition implies that the firm sets its optimal price as a markup over marginal cost:

$$
P_{t}(j, i)=\mathcal{M}_{t}(j, i) m c_{t}(j, i)
$$

where:

$$
\begin{aligned}
& \mathcal{M}_{t}(j, i)=\frac{\Theta_{t}(j, i)}{\left(\Theta_{t}(j, i)-1\right)} \\
& \Theta_{t}(j, i)=\theta-(\theta-\sigma) \underbrace{\left(\frac{P_{t}(j, i)}{P_{t}(i)}\right)^{1-\theta}}_{S_{t}(j, i)}
\end{aligned}
$$

and $m c_{t}(j, i)$ is the marginal cost of production, $\mathcal{M}_{t}(j, i)$ is the markup function and $\Theta_{t}(j, i)$ the price elasticity of demand to its own price. 
We denote $S_{t}(j, i)$ the share of firm $j$ in sector $i$ total expenditures:

$$
S_{t}(j, i)=\frac{P_{t}(j, i)}{P_{t}(i)} \frac{x_{t}(j, i)}{Y_{t}(i)}=\frac{P_{t}(j, i) P_{t}^{-\theta}(j, i)}{P_{t}(i) P_{t}^{-\theta}(i)}=\left(\frac{P_{t}(j, i)}{P_{t}(i)}\right)^{1-\theta}
$$

The markup, $\mu_{t}(j, i)$, can be written as a decreasing function of the equilibrium market share of firm $j, S_{t}(j, i)$. This is a very useful feature because, even though equilibrium markups are unobservable, the pro-competitive channel can be captured by expressing markups as a function of equilibrium markets shares, which we observe in the data.

Rewriting equation (14) in log:

$$
\begin{aligned}
& \log \left(P_{t}(j, i)\right)=\log \left(\mathcal{M}_{t}(j, i)\right)+\log \left(m c_{t}(j, i)\right) \\
& \frac{\partial \log }{\partial t}\left(P_{t}(j, i)\right)=\frac{\partial \log }{\partial t}\left(\mathcal{M}_{t}(j, i)\right)+\frac{\partial \log }{\partial t}\left(m c_{t}(j, i)\right)
\end{aligned}
$$

Besides,

$$
\frac{\partial \log }{\partial t}\left(\mathcal{M}_{t}(j, i)\right)=\underbrace{\left[-\frac{1}{\Theta_{t}(j, i)-1}\right]}_{\varepsilon_{\mathcal{M} \Theta}} \underbrace{\left[-(\theta-\sigma) \frac{S_{t}(j, i)}{\Theta_{t}(j, i)}\right]}_{\varepsilon_{\Theta S}} \frac{\partial \log }{\partial t}\left(S_{t}(j, i)\right)
$$

where $\varepsilon_{u v}$ denotes the elasticity of $u$ with respect to $v$.

In the end:

$$
\pi_{t}(j, i)=\varepsilon_{\mathcal{M} \Theta} \varepsilon_{\Theta S} \frac{\partial \log }{\partial t}\left(S_{t}(j, i)\right)+\frac{\partial \log }{\partial t}\left(m c_{t}(j, i)\right)
$$

Equation (16), applied to the domestic producer $(j=D)$, relates domestic producer price inflation in sector $i$ to changes in the domestic producer's market share. The latter is a function of the market shares of its foreign competitor: $S_{t}(D)=1-S_{t}(F)(\forall$ sector $i)$. Thus, equation (16) can be rewritten as a negative relationship between domestic firm's price and the share of foreign competitor in industry sales - i.e. import penetration:

$$
\pi_{t}(D, i)=\psi \frac{\partial \log }{\partial t}\left(S_{t}(F, i)\right)+\frac{\partial \log }{\partial t}\left(m c_{t}(D, i)\right)
$$


We obtain the empirical counterpart by appending a residual term $\mu_{i t}=\lambda_{t}+\nu_{i}+\epsilon_{i, t}$, where $\lambda_{t}$ is a time fixed-effect and $\nu_{i}$ is a sector fixed effect:

$$
\pi_{i, t}^{D}=\Psi \Delta S_{i, t}^{F}+\kappa \Delta \text { labcost }_{i, t}+\eta \Delta \text { inputcost }_{i, t}+\lambda_{t}+\nu_{i}+\epsilon_{i, t}
$$

where labcost $_{i, t}$ and inputcost $_{i, t}$ capture changes in the marginal cost of production. 


\section{Instruments}

In this Appendix, we provide details on the construction of the instrumental variables and present the results from the first-stage regressions. Our instrumental variable is defined as the product of the average French labor share $l s$ in sector $i$ and the annual growth rate of LWC manufacturing exports $\Delta X: x_{i t}=l s_{i} \times \Delta X_{t}$. The instrument provides sector $\times$ year variation obtained from the product of a time-varying country categorylevel variables $\Delta X_{t}$ and a time-invariant sector-level variable, $l s_{i} . l s_{i}$ is averaged over the period to reduce endogeneity concerns. Labor shares are calculated using firm-level balance-sheet quasi-exhaustive administrative data constructed from tax records, labeled "BRN" (Benefices Reels Normaux). We first sum the firm-level wage bill and valueadded for all firms in the same sector, we then define the labor share for each sector as the ratio of (wage bill)/(value added). Then we take the average across years. For the growth rate of exports $\Delta X_{t}$ we use data from the World Bank's Development Indicators Database. We obtain manufacturing exports by country and by year (in current dollars) as the product of annual merchandise exports and a variable indicating the proportion of manufacturing exports in merchandise exports. We sum exports of all LWCs to all destinations except France, then we calculate the year-on-year growth rate. In the case of the China share we use Chinese exports to all destinations except France.

The first-stage regression is the following:

$$
\Delta S_{i, t}^{L W C}=a+b x_{i, t}+c \Delta l a b c o s t_{i, t}+d \Delta \text { inputcost }_{i, t}+T_{t}+P_{i}+z_{i, t}
$$

where $\Delta S_{i, t}^{L W C}$ is the variation of the share of imports from China in domestic consumption of good $i, x_{i t}$ is our instrumental variable, $\Delta$ labcost is the annual growth rate of labour cost in sector $i$ and $\Delta$ inputcost the annual change in input cost for sector $i, T_{t}$ is a time fixed-effect and $P_{i}$ is a product fixed effect, $z_{i, t}$ is the residual term.

The second stage equation is as defined in the main text by equation (6). 
Table A reports results of the first-stage estimation. The first stage results show that our instrument has a significant positive effect on the change in LWC / Chinese import penetration.

Table A: Results of first-stage estimation

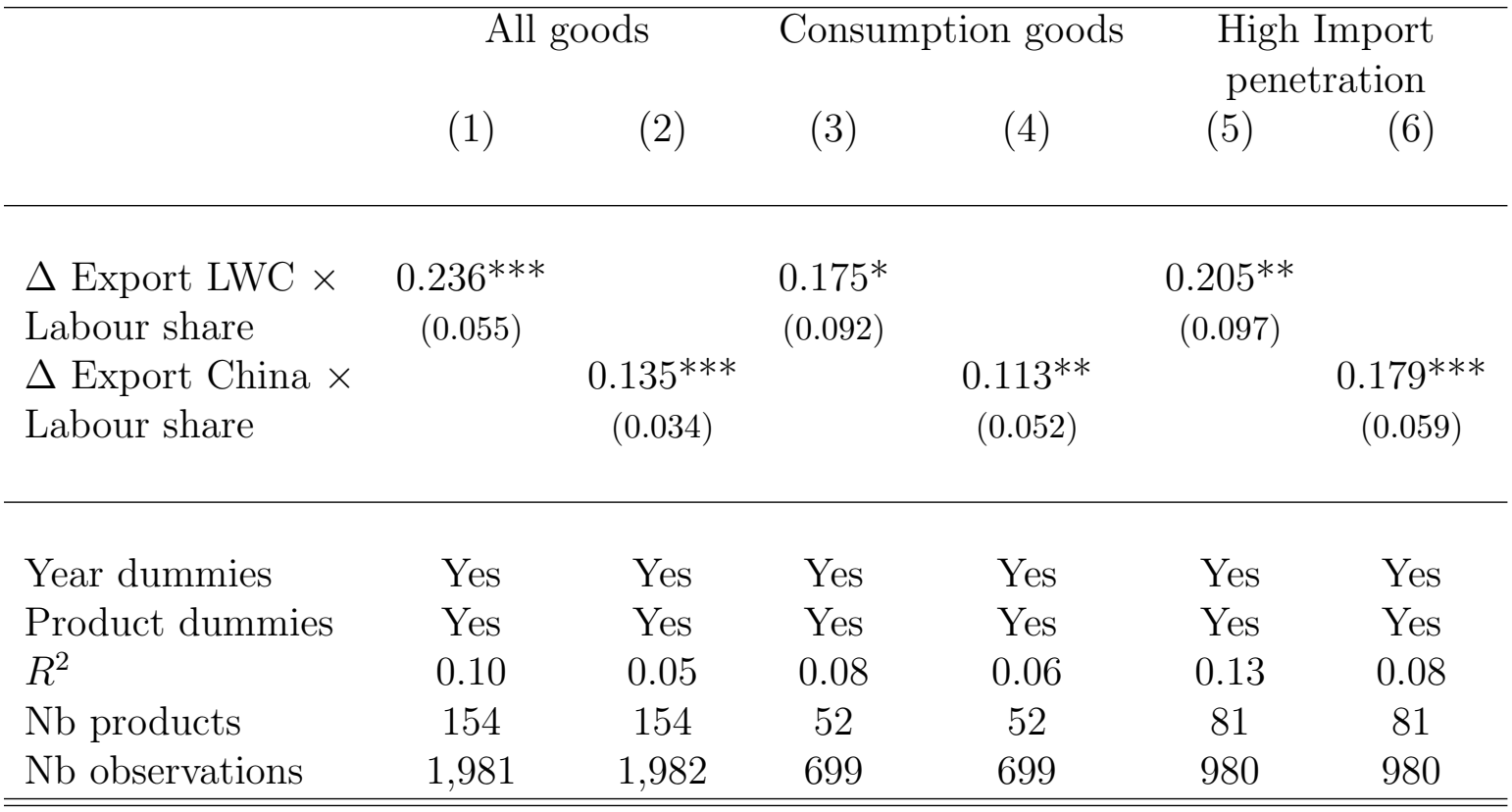

Note: this table reports first-stage estimates of our IV regressions where the dependent variable is " $\Delta$ Export LWC $\times$ Labour share", the annual change in LWC manufcaturing exports (source: WTO) times the average labour share calculated at the product-level (source: administrative firm-level data). Year (19 years) and product (154 products) dummies are included, controls for annual growth rate of intermediate input costs and labour costs at the sectoral level (level 2 of NACE classification, source: Stan OECD) are also included. Robust standard errors are reported in brackets. "All goods" include all goods for which producer price inflation is available, "'Consumption goods"' include goods that can be match with CPI classification. 